\title{
Preferable Districts for Groundwater Exploitation Based on Hydrogeologic Data of Aquifers-West Iraq
}

\author{
Bayan Muhie Hussien, Abed Salih Fayyadh \\ Center of Desert Studies, University of Al-Anbar, Iraq \\ Email: bayan1959@yahoo.com
}

Received 21 July 2014; revised 15 August 2014; accepted 8 September 2014

Copyright (C) 2014 by authors and Scientific Research Publishing Inc.

This work is licensed under the Creative Commons Attribution International License (CC BY).

http://creativecommons.org/licenses/by/4.0/

c) (i) Open Access

\begin{abstract}
The study examines the hydrogeological conditions and the hydraulic characteristics of the water bearing horizons within the hydrogeologic regime of the study area located west of Iraq to the west of longitude $40^{\circ} 40^{\prime}$. Also the study shed light on the flow behavior regime and its impacts on the groundwater movement, ground water flow velocities (permeability and hydraulic gradients) considering the regional structural phenomena. The Hydrogeological data presented as spatial distribution maps and three dimensional models. The results which were achieved from the field measurements are correlated with the main hydrogeologic control points such as storage and transmissivity coefficients, groundwater depths, aquifers thickness, lateral extensions and groundwater recharge to classify the hydrogeologic districts for development and exploitation. The hydrogeologic regime of the study area is classified and screened into various aquifers, including Ga'ra, Mullusi, Mullusi-Ubaid, Hartha, Tayarat-Digma (Jeed), Muhaywir-Ubaid and Rattga aquifers. The statistical results of the hydraulic and hydrochemical parameters were examined for explaining the spatial distribution of each parameter within the uppermost aquifers and determining the preference hydrogeologic districts for future groundwater exploitation as hereinafter order, Ubaid Mullusi aquifer within district-6, Rattga and Digma-Tayarat aquifer within district-7, Mullusi aquifer within district-2, Hartha aquifer within district-3, Digma-Tayarat aquifer within district-4, Ga'ra aquifer within district-1, Muhaywir-Ubaid aquifer within district-5 and DigmaTayarat within district-8, respectively.
\end{abstract}

\section{Keywords}

Hydraulic Parameters, Exploitation, Aquifer, Groundwater Flow, Groundwater Velocity 


\section{Introduction}

The identification of aquifer systems are of main requirements in the various hydrogeological studies. A significant contribution of structural, hydrodynamics and geologic boundaries are used for defining aquifer characteristics [1]-[3]. Subsurface integrated hydrogeological technique explains the hydrogeologic model of the water bearing horizons and the groundwater occurrence. Hydrodynamic characterization is used in determining the groundwater resources and behaviour of groundwater flow and groundwater balance [4]-[9]. The stratigraphic facts, structural settings and hydrogeologic boundaries are used in the explanation of hydrogeologic phenomena and in estimation of aquifers storage throughout geometry model of aquifers system and their storage coefficients, while the groundwater levels, permeability and transmissivity coefficients are lead to estimate groundwater recharge, groundwater velocity and flow, productivity of wells and feeding ratios from mixed water bearing horizons [10]-[15].

The aim of the study is to determine the aquifers systems by quantitative and qualitative evaluation, using hydrogeologic facts as bilateral hydrogeological (hydraulic and hydrochemical) maps and three dimensional hydro-stratigraphic models. Also aimed to select the best hydrogeologic districts within Iraqi western zone and then be developed for groundwater exploitation. The selection of preferable districts was achieved by screening the available hydrogeologic data of aquifers. Physiographically, the study area which obtained 266 water wells is located within Hamad and Upper wedian zones to the west of longitude $40^{\circ} 40^{\prime}$ (west Iraq), crossed by the express ways which joins Rutba city with Tenif and Traybil borders Sites. It is bounded by Syria, Jordan and Arabia Saudia borders with an area of about $(39,000) \mathrm{km}^{2}$ and altitude ranged from 262 to $834 \mathrm{~m}$ asl, (Figure 1). The morphological features were influenced by Pleistocene rainy periods represented by multi-drainage patterns within the hydrologic basins of the valleys Hauran, Rattga, Akash, Swab, Alwalaj, Kharja, Elattra, Elmerbagh and the tributaries of Ubayidh and Ghadaf valleys. These valleys are characterized by increasing of lengths, expanding of widths, presence of old soils with gravels aggregates, karst sinkholes, rocks creep, and presence of meandering valleys with many break off in their long sectors which indicate high powers of water discharge [16]. The land surface distinguished as a plateau having undulant step reliefs, gradually rises from north east towards south west (Figure 1).

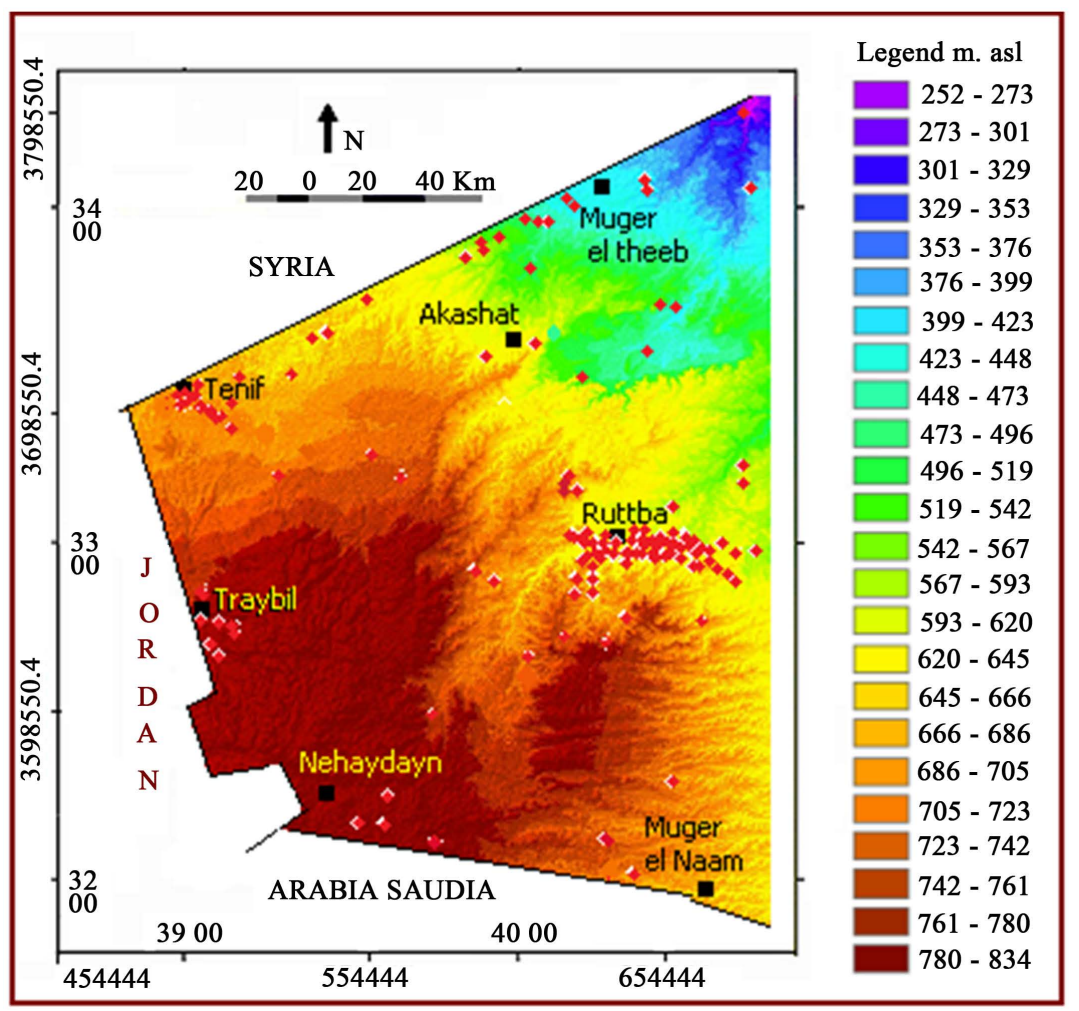

Figure 1. Topographic map showing location of water wells. 
The slope of the land surface is $2.85 \mathrm{~m} / \mathrm{km}$ towards east and $3.57 \mathrm{~m} / \mathrm{km}$ towards north east ranged from 0.5 $\mathrm{m} / \mathrm{km}$ to $14 \mathrm{~m} / \mathrm{km}$. Several seasonal valleys cross the area forming number of plateaus with accumulation of pediment sediments on their edges [17]. Heterogeneous sediments are found in the vertical and horizontal extensions due to variability of rocks forming geologic formations such as limestone, dolomite, sandstone, marly limestone, and clay. The study area is located at the southern part of the northern subtropical zone of the earth, westerly connected with deserts of Al-Sham and Arabia peninsula, which is mainly influenced by dry arid climate with low impact of the Mediterranean Sea climate. The mean annual values of air temperature, relative humidity, speed of winds, rainfall, and evaporation which were recorded in Rutba meteorological station during the period between 1941 and 2013 are shown in Table 1.

The hours of sun brightness are ranged between 6.1 hour/day and 12.4 hour/day, with an average of radiation energy ranged from 276 to $733 \mathrm{kilowatt} / \mathrm{m}^{2} /$ day. The prevailing directions of winds are from west and northwest during the months of summer and spring seasons, while remainders of the directions are of irregular occurrence, especially the eastern winds. According to classification of United Nations Environment Programme, [18] and depending on the ratio of rainfall (P) divided by evapotranspiration (PE), the ratio $\mathrm{P} / \mathrm{PE}$ is amounted between 0.046 and 0.077 in an average of 0.063 , the climate of the study area is classified within the arid zone, which reflects drought case of negative impacts on the groundwater recharge during the second half of the twentieth century and the thirteenth years of the present century.

\section{Methods and Materials}

On the basis of available lithologs of sixteen key boreholes [19]-[22] using Rockware-14 software, a 3D hydrogeologic models were performed to identify the distribution of the hydrogeologic system and their hosted geologic formations in $\mathrm{X}, \mathrm{Y}$ and $\mathrm{Z}$ directions. This would facilitate the impact of hydro-stratigraphy and geostructural change on the flow regime. The aquifers properties and groundwater flow were examined using their hydraulic parameters (Table 2) and groundwater levels measured during June 2013. Data base comprised TDS and pH measurements were performed during same period (June 2013). Based on hydraulic information, a groundwater flow model was created to determine the groundwater recharge and/or replenishment [23] and groundwater velocity within aquifers. Static/dynamic water levels and water discharges are measured in the wells using electrical sounder for levels and volumetric-time method for discharge application, depending on the procedures mentioned in [13] [24]-[32].

Groundwater Contour program is used in finding 2D spatial groundwater flow maps, while ArcGis 9.3 program used for compilation other maps. The hydro-stratigraphic boundaries are used along with structural setting to build a conceptual model of the hydrogeologic flow system, where the three dimensional hydrogeologic models provide significant advantages when conducting groundwater resource assessments which lead to improve resource management outcomes.

The evolution of three dimensional geological model has been worked on around the world [33] [34]. Also, a comprehensive coverage of the current activities in hydrogeologic field was provided by the Illinois State Geological Survey website [35]. Hydraulic and hydro-chemical parameters are interpreted in a statistical manner for the purpose of high accurate level, after plotting their values against percent of wells (Fs \%), on a probability-logarithm graph paper [25]. Fs $\%=\left[\mathrm{M}_{0} /\left(\mathrm{N}_{\mathrm{w}}+1\right)\right] \times 100$, where, Fs \%: frequency of wells; $\mathrm{M}_{0}$ : order number; $\mathrm{N}_{\mathrm{w}}$ : total of wells. Seven hydraulic and hydrochemical criteria are used in ranking among eight hydrogeologic districts to reach the best preferable districts, which have been chosen for exploitation plans and groundwater managements. These Criteria are converted into quantitative weight, accordingly, the district which gathered high weight scores, classified as a preferable one.

Table 1. Temperature, relative humidity, rainfall and evaporation recorded in Rutba station.

\begin{tabular}{cccccc}
\hline Climate factors & $\begin{array}{c}\text { Temperature } \\
{ }^{\circ} \mathrm{C}\end{array}$ & $\begin{array}{c}\text { Relative } \\
\text { humidity\% }\end{array}$ & $\begin{array}{c}\text { Wind speed } \\
\mathrm{m} / \mathrm{sec}\end{array}$ & $\begin{array}{c}\text { Rainfall } \\
\mathrm{mm} / \text { year }\end{array}$ & $\begin{array}{c}\text { Evapotranspiration } \\
\text { mm/year }\end{array}$ \\
\hline Range & $12.95-27.4$ & $26.3-72.5$ & $2.14-4.15$ & $78.1-131.9$ & $1691-1703$ \\
Mean annual & 20.12 & 45.6 & 3.12 & 106.9 & 1686.1 \\
\hline
\end{tabular}


Table 2. Hydraulic data of aquifers within study area.

\begin{tabular}{|c|c|c|c|c|c|}
\hline Water point & Specific capacity (m³/day/m) & $\mathrm{K}$ (m/day) & $\mathrm{T}\left(\mathrm{m}^{2} /\right.$ day $)$ & Storativity & Remark \\
\hline BH58 & 61.3 & 0.2 & 200 & 0.0094 & Ga'ra Aquifer. D1 \\
\hline BH59 & 60.0 & 0.4 & 37.0 & 0.0086 & Ga'ra Aquifer. D1 \\
\hline BH104 & 105.2 & 0.01 & / & 0.0084 & Ga'ra Aquifer. D1 \\
\hline $\mathrm{BH} 4$ & 7.95 & 0.35 & 27.3 & / & Mullusi-Ga'ra. D2 \\
\hline BH6 & I & 2.8 & 161 & 0.0065 & Mullusi-Ga’ra. D2 \\
\hline BH7 & 17.21 & 0.8 & 48.0 & / & Mullusi-Ga’ra. D2 \\
\hline BH9 & / & 0.036 & 2.27 & 0.0273 & Mullusi-Ga'ra. D2 \\
\hline BH10 & 15.71 & I & / & I & Mullusi-Ga'ra. D2 \\
\hline BH11 & 9.30 & 0.1 & 10.0 & 0.007 & Mullusi-Ga'ra. D2 \\
\hline BH12 & 18.0 & 1.23 & 43.0 & I & Mullusi-Ga’ra. D2 \\
\hline BH13 & 8.10 & 0.35 & 19.0 & 0.009 & Mullusi-Ga’ra. D2 \\
\hline BH15 & 15.62 & 0.065 & 6.38 & I & Mullusi-Ga'ra. D2 \\
\hline BH17 & 19.57 & 0.286 & 36.057 & 0.000264 & Mullusi-Ga'ra. D2 \\
\hline BH18 & 3.35 & / & / & / & Mullusi-Ga’ra. D2 \\
\hline BH20 & 7.17 & 0.13 & 32.0 & 0.0034 & Mullusi-Ga'ra. D2 \\
\hline BH22 & I & I & / & I & Mullusi-Ga'ra. D2 \\
\hline $\mathrm{BH} 23$ & 6.03 & 0.2 & 31.0 & I & Mullusi-Ga'ra. D2 \\
\hline BH24 & I & I & l & I & Mullusi-Ga'ra. D2 \\
\hline BH25 & 7.25 & 0.031 & 1.896 & 0.00219 & Mullusi-Ga'ra. D2 \\
\hline BH26 & 4.00 & I & / & I & Mullusi-Ga'ra. D2 \\
\hline BH28 & 5.18 & / & / & 0.0063 & Mullusi-Ga’ra. D2 \\
\hline ВH29 & 3.97 & 0.37 & 38.0 & I & Mullusi-Ga'ra. D2 \\
\hline ВН30 & I & 0.4 & I & I & Mullusi-Ga'ra. D2 \\
\hline ВH31 & 3.75 & 0.0078 & 1.06 & 0.0004 & Mullusi-Ga’ra. D2 \\
\hline ВН33 & 3.23 & I & l & I & Mullusi-Ga'ra. D2 \\
\hline BH35 & 13.98 & I & / & I & Mullusi-Ga'ra. D2 \\
\hline BH36 & 4.20 & 0.3 & 29.0 & 0.0007 & Mullusi-Ga'ra. D2 \\
\hline ВН38 & 7.48 & I & l & I & Mullusi-Ga'ra. D2 \\
\hline ВН39 & I & 0.09 & I & I & Mullusi-Ga'ra. D2 \\
\hline BH40 & 6.65 & 0.51 & 46.0 & / & Mullusi-Ga'ra. D2 \\
\hline BH41 & I & 0.38 & 26.0 & 0.0006 & Mullusi-Ga'ra. D2 \\
\hline BH42 & I & 1.38 & I & I & Mullusi-Ga'ra. D2 \\
\hline BH43 & 11.6 & I & 247 & I & Mullusi-Ga'ra. D2 \\
\hline BH44 & 17.2 & 1.6 & 450 & I & Mullusi-Ga'ra. D2 \\
\hline BH45 & 5.18 & I & 2.6 & 0.01 & Mullusi-Ga’ra. D2 \\
\hline BH46 & 6.90 & 0.03 & 0.8 & 0.01 & Mullusi-Ga'ra. D2 \\
\hline BH47 & 8.60 & 0.3 & 18.0 & 0.0002 & Mullusi-Ga’ra. D2 \\
\hline BH48 & 5.23 & 0.25 & 2.0 & 0.0005 & Mullusi-Ga'ra. D2 \\
\hline BH49 & 7.17 & 0.34 & 3.0 & 0.0005 & Mullusi-Ga'ra. D2 \\
\hline BH54 & / & 0.09 & 67.0 & 0.01 & Mullusi-Ga'ra. D2 \\
\hline
\end{tabular}




\section{Continued}

\begin{tabular}{|c|c|c|c|c|c|}
\hline BH55 & 12.1 & 4.4 & 249 & / & Mullusi-Ga'ra. D2 \\
\hline BH61 & 7.80 & 1.3 & 161 & / & Mullusi-Ga'ra. D2 \\
\hline BH62 & / & 0.1 & 4.0 & / & Mullusi-Ga’ra. D2 \\
\hline BH63 & I & 0.1 & 14.0 & 0.002 & Mullusi-Ga’ra. D2 \\
\hline BH66 & I & 0.5 & 95.0 & / & Mullusi-Ga'ra. D2 \\
\hline BH67 & / & 0.7 & 170 & 0.0026 & Mullusi-Ga’ra. D2 \\
\hline BH68 & I & 3.4 & 632 & I & Mullusi-Ga'ra. D2 \\
\hline BH69 & 33.0 & 0.4 & 38.0 & 0.0021 & Mullusi-Ga’ra. D2 \\
\hline BH70 & 21.0 & I & / & 0.0044 & Mullusi-Ga’ra. D2 \\
\hline BH76 & 12.0 & 0.73 & 16.0 & / & Mullusi-Ga’ra. D2 \\
\hline BH81 & 2.19 & / & / & / & Mullusi-Ga'ra. D2 \\
\hline BH88 & 8.64 & I & I & 0.001 & Mullusi-Ga’ra. D2 \\
\hline BH90 & 70.7 & 3.0 & 300 & / & Mullusi-Ga’ra. D2 \\
\hline BH94 & / & 0.2 & 17.0 & 0.009 & Mullusi-Ga'ra. D2 \\
\hline BH98 & 12.47 & 0.036 & 7.128 & / & Mullusi-Ga'ra. D2 \\
\hline BH107 & 12.57 & 0.1 & 13.0 & / & Mullusi-Ga’ra. D2 \\
\hline BH116 & 3.30 & / & 17.0 & / & Mullusi-Ga'ra. D2 \\
\hline BH64 & 44.0 & 0.1 & 4.0 & 0.01 & Hartha-Ga’ra. D3 \\
\hline BH65 & 24.0 & 1.3 & 200 & 0.013 & Hartha-Ga’ra. D3 \\
\hline BH5 & 39.8 & 0.2 & 20.0 & 0.006 & Digma-Tayarat. D4 \\
\hline BH16 & 35.0 & 0.2 & 15.0 & 0.0061 & Digma-Tayarat. D4 \\
\hline BH60 & 22.0 & 0.6 & 250 & 0.0068 & Digma-Tayarat. D4 \\
\hline BH93 & 51.2 & 1.2 & 64.0 & 0.0053 & Digma-Tayarat. D4 \\
\hline BH100 & 30.2 & 0.8 & 180 & 0.008 & Digma-Tayarat. D4 \\
\hline BH72 & 11.2 & 1.2 & 74.2 & 0.018 & Muhaywir-Ubaid. D5 \\
\hline BH37 & 6.62 & 0.3 & 0.64 & 0.02 & Ubaid-Mullusi. D6 \\
\hline BH50 & 7.94 & 0.2 & 5.0 & 0.016 & Ubaid-Mullusi. D6 \\
\hline BH51 & 13.0 & 0.4 & 23.0 & 0.018 & Ubaid-Mullusi. D6 \\
\hline BH53 & 32.0 & 4.4 & 0.7 & 0.01 & Ubaid-Mullusi. D6 \\
\hline BH91 & 47.0 & 0.1 & 16.0 & 0.009 & Ubaid-Mullusi. D6 \\
\hline BH8 & 7.86 & 0.1 & 15.0 & 0.004 & Ratga-Digma-Tayarat. D7 \\
\hline BH101 & 12.3 & 1.9 & 88.0 & 0.0046 & Ratga-Digma-Tayarat. D7 \\
\hline BH102 & 5.07 & 0.2 & 27.0 & 0.0042 & Ratga-Digma-Tayarat. D7 \\
\hline BH103 & 44.3 & 6.2 & 90.0 & 0.0038 & Ratga-Digma-Tayarat. D7 \\
\hline BH111 & 4.96 & 0.3 & 6.0 & 0.0041 & Ratga-Digma-Tayarat. D7 \\
\hline BH112 & 6.7 & 0.3 & 9.0 & 0.003 & Ratga-Digma-Tayarat. D7 \\
\hline BH113 & 19.1 & 1.2 & 90.0 & 0.0044 & Ratga-Digma-Tayarat. D7 \\
\hline BH114 & 33.3 & 4.2 & 40.8 & 0.0032 & Ratga-Digma-Tayarat. D7 \\
\hline BH157 & 16.2 & 0.43 & 110 & 0.005 & Ratga-Digma-Tayarat. D7 \\
\hline BH56 & 122 & 0.25 & 6.4 & 0.009 & Digma-Tayarat. D8 \\
\hline BH57 & 48.0 & 0.2 & 42.2 & 0.0086 & Digma-Tayarat. D8 \\
\hline BH115 & 158.4 & 0.2 & 319 & 0.01 & Digma-Tayarat. D8 \\
\hline
\end{tabular}




\section{Results and Discussions}

\subsection{Geomorphologic and Structural Boundaries}

The plateaus in the study area are existed on multi-levels of elevations with NW-SE extension within the Iraqi desert. The south western plateau of an elevation ranged between $733 \mathrm{~m}$ asl and $900 \mathrm{~m}$ asl incised by Hauran, Kharja, Atra, Gheri, Alwalaj valleys and the tributaries of Ubayidh and Ghadaf valleys. Valleys are the obvious morphologic features in the study area, which their drainage basins are considered as important zones that recharge aquifers. The drainage basins (Figure 2) vary in shape and area, where the large one is Rattga basin of oval shape formed $24 \%$ of total area obtaining Ga'ara depression, influenced by structural processes (Rutba uplift), followed by Hauran basin of rectangular shape formed $22 \%$ of study area influenced by Hauran anticlinorium, followed by parts of Ubayidh and Ghadaf triangle basin represents $18 \%$ of steady area, then followed by Alwalaj, Elmerbagh-Kharja, Swab and Akash basins with a percent area of $17 \%, 8 \%, 6 \%$ and 5\%, respectively. The drainage of the main valleys is of parallel and dendritic patterns controlled by rock type and heterogeneity of sediments. Systems of blind central dendritic valleys are existed in Elmerbagh-Kharja basin and Breem valley within Alwalaj basin which ends in a plain filled by friable sediments. The depression that formed as a results of weathering process and karstification (such as Mchaymin depression) [36] are considered as important land forms within the lands of Hauran and Alwalaj basins. The depression fill sediments overlay the plateaus surface

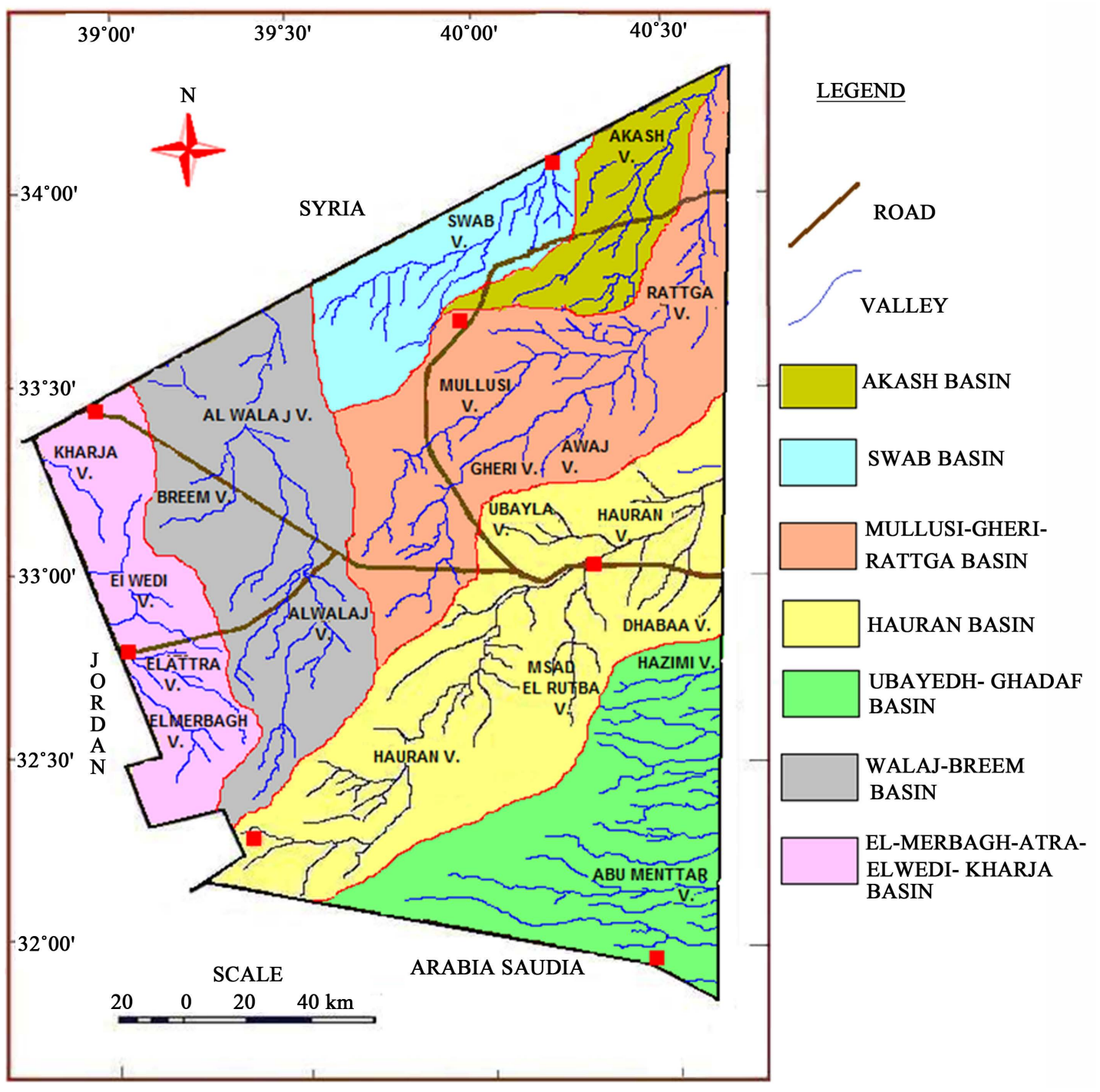

Figure 2. Distribution map of hydrologic basins. 
in areas of few square meters to few square kilometers. The depressions may be originated to the dissolution of fractured carbonate rocks influenced by structural and stratigraphic settings (joints and bed plane). The active winds and sheet runoff may participate in filling depressions by sands, clays, and silts. The largest depression in the study area is Ga'ra oval depression with an area of about $2000 \mathrm{~km}^{2}$ has east-west extension.

The depression is slightly undulated and the hydrologic status depends on the quantity of waters received by Gheri, Mullusi and the other surrounding valleys from several sides. Level of waters rises during season of rains detains for a short time and then large quantity of water was lost as a result of evaporation and infiltration process, some times during intense rainstorms a surplus runoff outflows from depression through Halgom gully towards Rattga valley. Ga'ra depression was formed by the impact of runoff activity and sediments transport from sandstones and claystones of Ga'ra Formation (erosion process). Structurally, the study area is a part of Rutba subzone within the western zone of the stable shelf related to Arabic-African plate within Rutba subzone [37]. A rock ware program (RW-14) is used in accomplishment of the Hydro-structure model depending on geologic information represented by lithologic sections of wells. Results of the model (Figure 3) show that the water bearing horizons in Iraqi western desert influenced by Hauran fold (anticlinorium) with beds dipping from $1.0^{\circ}$ to $2.0^{\circ}$ in a direction of ESE and from $2.0^{\circ}$ to $6.0^{\circ}$ in a direction of WSW, NWN and NEN [38]-[40]. The model also explains the lateral and vertical extension of geologic formations within the general geo-structure setting of the area. Hauran anticlinorium characterized by dome plateau shape (Rutba uplift), related to the basement mass movement occurred on the extension of Hail regional arc during Paleozoic [37].

The zone of fold axis forms regional groundwater divide [41] which controls the groundwater recharge and movement by deviating water towards SE (Nukhaib Depression), N (Ga'ra depression) and NW (Traybil-Tinf karistic replenished zone). One hundred and ninety one lineaments are dedicated from compiled structure map [37] [42] and geophysical gravity map [43]. The lineaments phenomena confirmed direct impact of Rutba Uplift on the extension of geologic Formation and morphologic features which possibly affect the groundwater recharge through exposure rocks. The percent of lineaments in a direction of WNW-ESE, which influenced by Najid orogeny is the dominant and has a percent of $35 \%$ from the total lineaments. The percent of lineaments in a direction of ENE-WSW and E-W which influenced by Laramide and Alpine orogeny is of about $34 \%$ and $15 \%$ from the total lineaments, respectively. The effectiveness of Hejaz orogeny reflected by vertical uplift accompanied with horizontal drift creates N-S lineaments. These lineaments trend has a percent of $16 \%$.

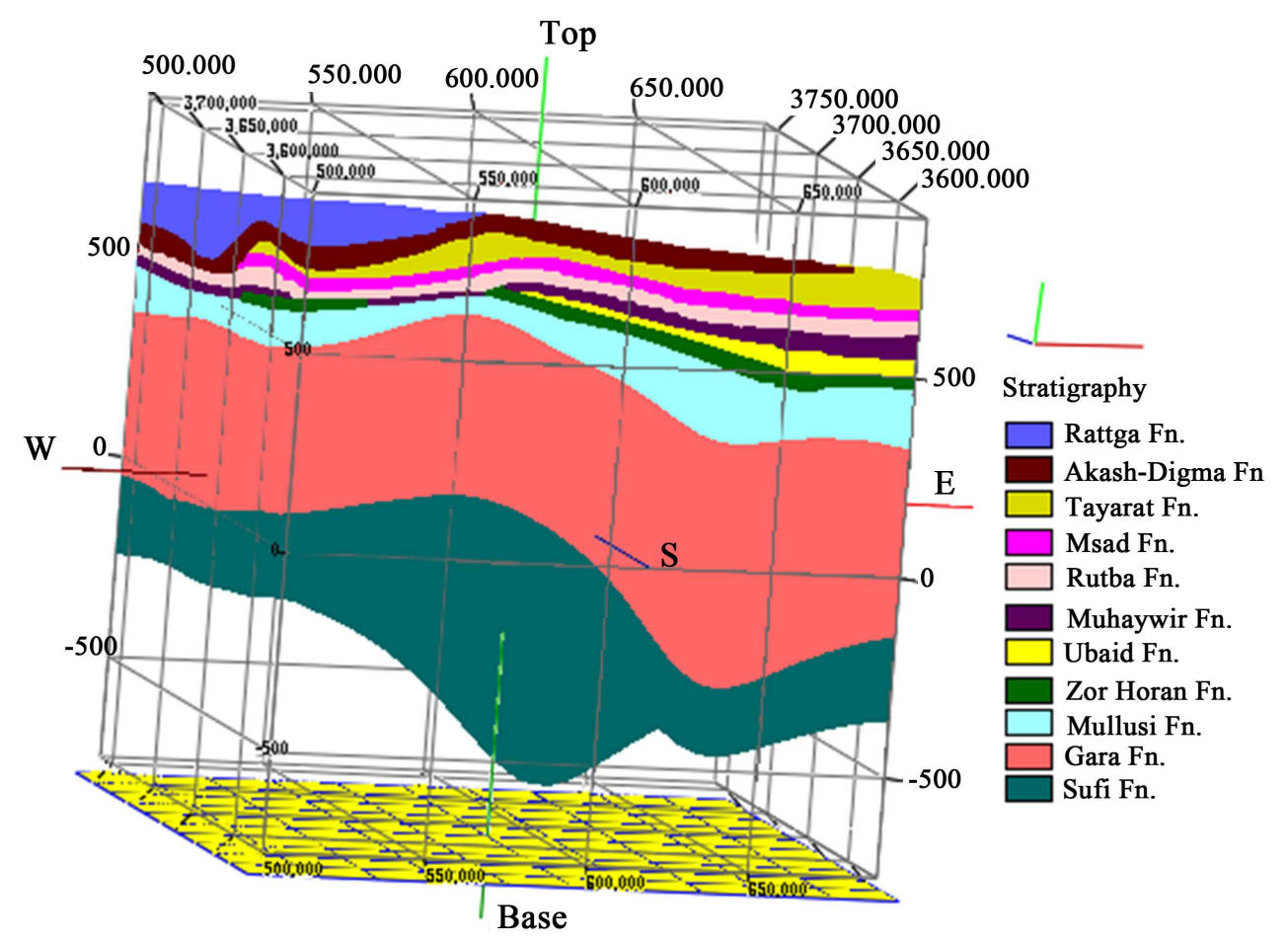

Figure 3. Geo-structural model of the study area. 


\subsection{Geologic and Hydrogeologic Boundaries}

According to the geologic studies of [44]-[49], a representative geologic section was summarized in Table 3 . The horizontal and vertical extensions of the Geologic Formations are explained in a surface geologic map and 3d geologic model as shown in Figure 4 and Figure 5, respectively. Depending on the groundwater occurrence within the water bearing horizons of the geologic Formation, eight hydrogeologic districts are determined (Figure 6), including:

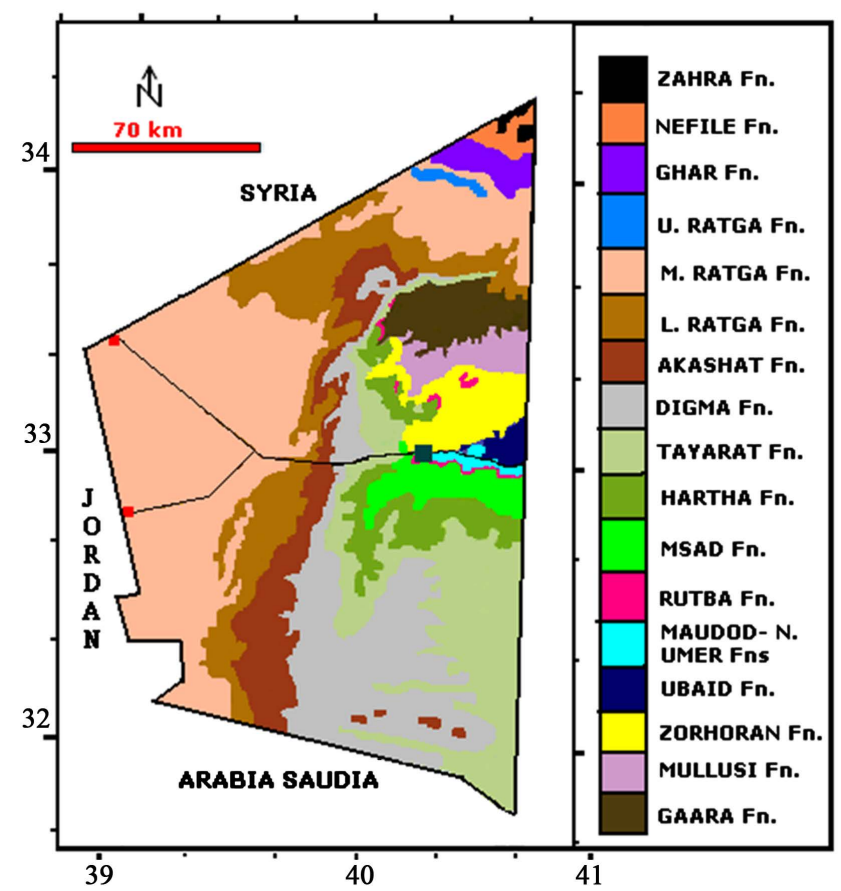

Figure 4. Geologic map of the study area, [37].

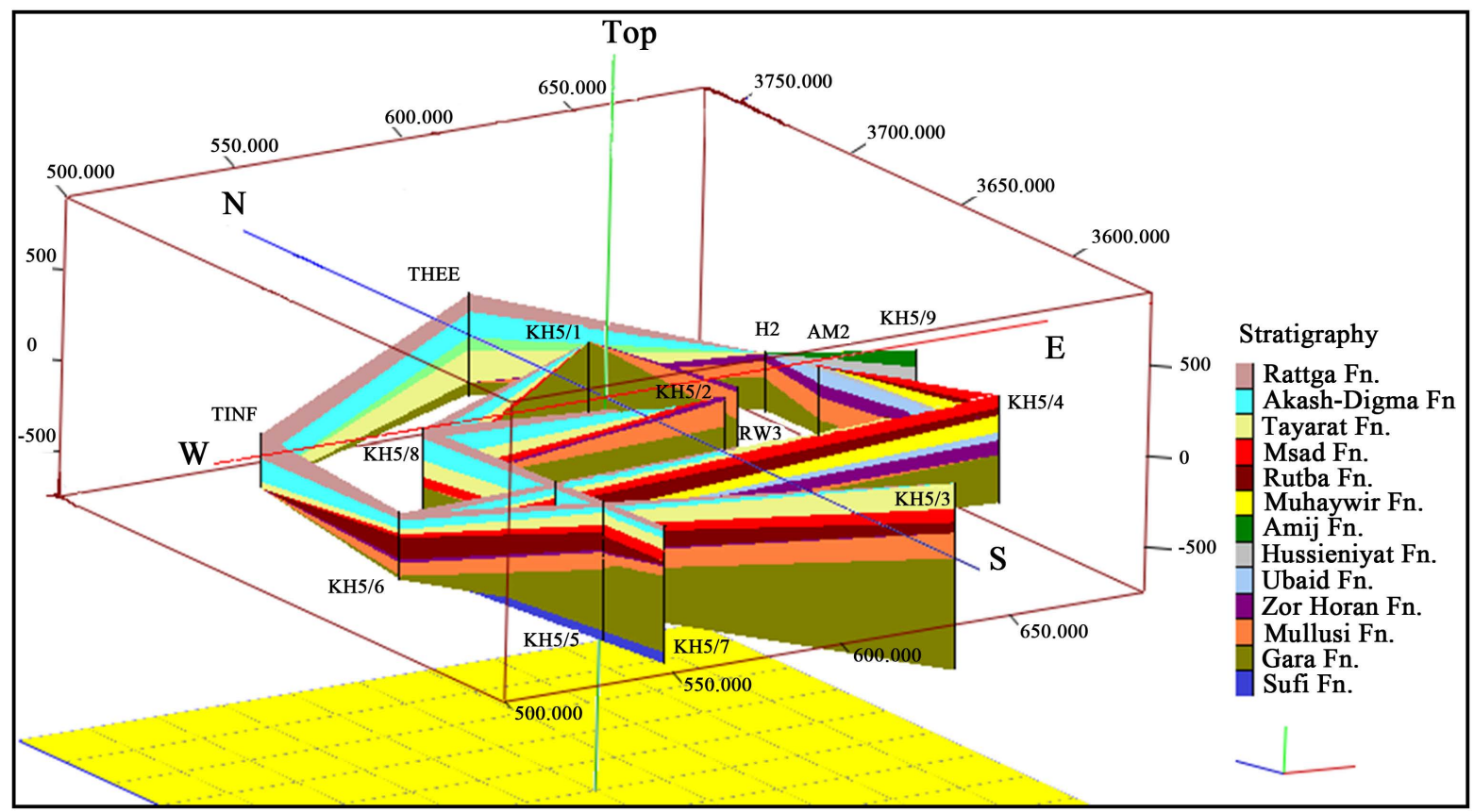

Figure 5. Three dimensional geologic model. 


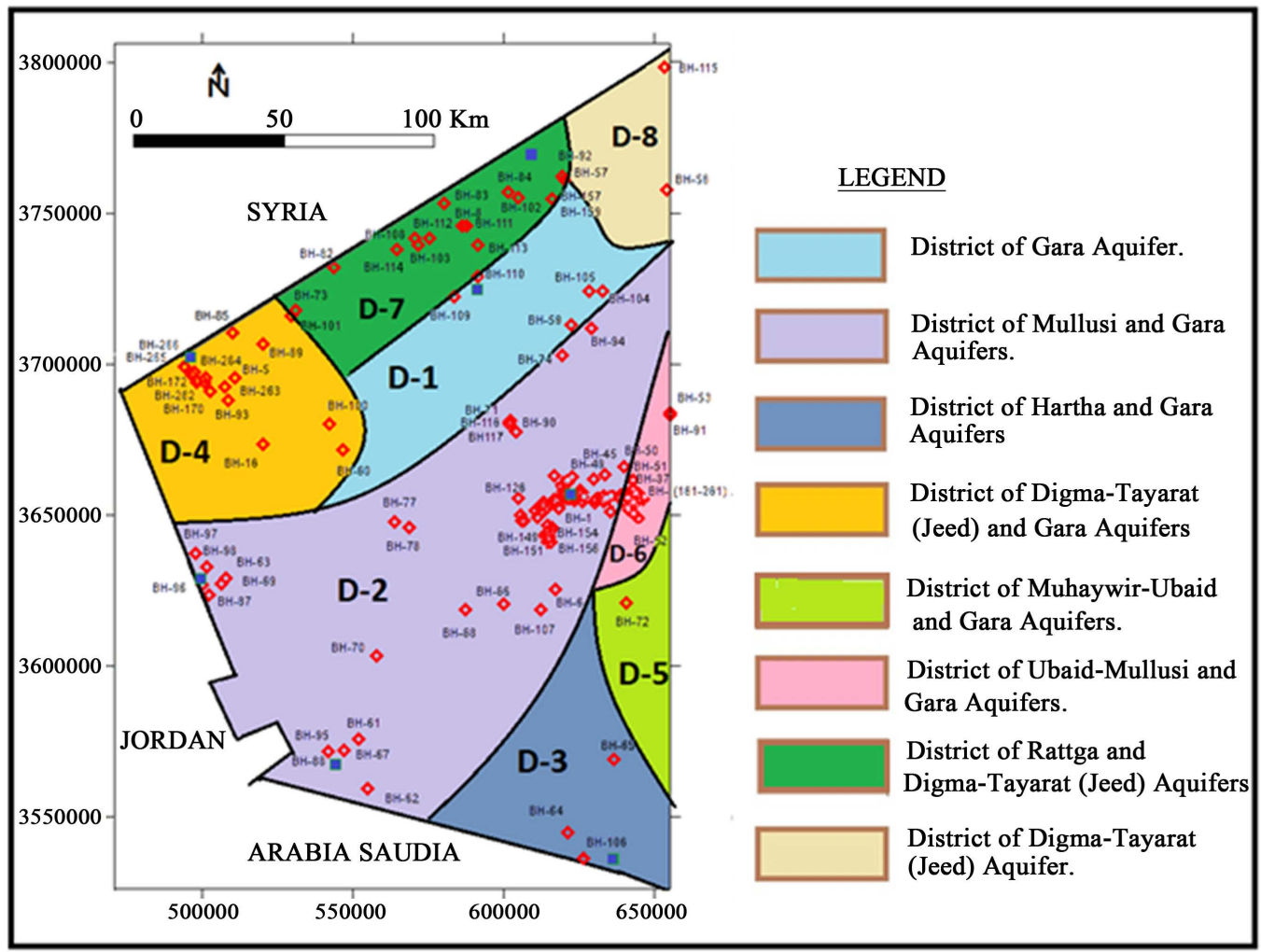

Figure 6. Spatial distribution map of districts and aquifers.

Table 3. Geologic sequences within study area.

\begin{tabular}{|c|c|c|c|c|}
\hline Era & Period & Age & Formation & Explanation \\
\hline \multirow{6}{*}{ 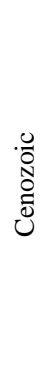 } & Quaternary & Holocene-Pleistocene & $\begin{array}{l}\text { Recent sediments, } \\
\text { Hauran Sandy gravel. }\end{array}$ & $\begin{array}{l}\text { Alluvial sediments, valley \& } \\
\text { depression fills, etc. }\end{array}$ \\
\hline & \multirow{5}{*}{$\begin{array}{l}\text { Tertiary } \\
\text { p }\end{array}$} & Late Miocene-Pliocene & Zahra Fn. & Limestone, sandy Limestone. \\
\hline & & Middle Miocene & Nefile Fn. & Marl, silty claystone, Limestone. \\
\hline & & Early Oligocene & Shurau/shiekh Alas Fns. & Carbonate rocks. \\
\hline & & Early-Late Eocene & Rattga Fn. & Fossiliferous dolomitic chalky, phosphatic Limestone \\
\hline & & Middle-Late Paleocene & Akashat Fn. & $\begin{array}{l}\text { Phosphatic limestone, marly Dolostone. } \\
\text { Chalky Fossiliferous Limestone. }\end{array}$ \\
\hline \multirow{9}{*}{ 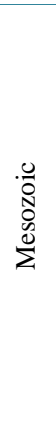 } & \multirow{5}{*}{ Cretaceous } & Early-Late Maestrichtian & Digma Fn. & $\begin{array}{l}\text { Sandy limestone interbedded with silty sandstone. } \\
\text { Marl and Dolomite. }\end{array}$ \\
\hline & & Late Campanian-Late Maestrichtian & Hartha-Tayarat Fns. & Dolomitic limestone, silty clay Limestone sandy, Marl. \\
\hline & & Cenomanian-Turonian & Rutba-Msad Fns. & Dolomitic Limestone-silty sandstones \\
\hline & & Albian-Cenomanian & Naher Umer-Maudod Fns. & Silt, Sandstone, Marl, dolostone, Limestone \\
\hline & & Bathonian & Muhaywir Fn & Marl, sandstones, carbonate \\
\hline & \multirow[t]{2}{*}{ Jurassic } & Lias & Amij-Hussayniyat Fns. & Claystones, sandstones, Iron Ore and dolomite \\
\hline & & Lias & Ubaid Fn. & Dolomite, Gypsious, Marl, Dolomitic Limestone \\
\hline & \multirow{2}{*}{ Triassic } & Rhaetic & Zor Hauran Fn & Marl, marly Limestone, Dolostone, Gypsious Marl \\
\hline & & Carnian-Nornian & Mullusi Fn. & Limestone, dolomite limestone, and dolostone. \\
\hline 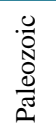 & Permo-carboniferous & Early-late Permian & Ga’ra Fn. & Interbedded of clay stones \& sandstones \\
\hline
\end{tabular}


-District of Ga'ra aquifer (D1): The district with area of about $5460 \mathrm{~km}^{2}$ includes Ga'ra depression and its vicinity area. The groundwater occurrence is in the siltstones and sandstones layers, which formed the water bearing horizons of Ga'ara Formation, while the unsaturated zone composed of limestone, marly limestone, and dolostone forming layers of Mullusi, Hartha, Digma, and Akashat Formations.

-District of Mullusi aquifer (D2): The major district with an area of about 14,000 $\mathrm{km}^{2}$ was found within the zones of Rutba-Traybil-Nihaydin Sites. The groundwater exists in Mullusi carbonate beds. The zone of unsaturation comprises stratigraphic beds of Zor Hauran, Husayniyat, Rutba, Msad, Hartha, Tayarat, Digma, Akashat, and Rattga Formations.

-District of Hartha aquifer (D3): The district with an area of about $4680 \mathrm{~km}^{2}$ is located at the southern part towards Saudi Arabia borders (Figure 6). The groundwater occurrence is in Hartha water bearing horizons, while unsaturation zone included layers of Tayarat and Digma Formations.

-District of Digma-Tayarat aquifer (D4): The district area is of about $5070 \mathrm{~km}^{2}$ located in the NW portion (Tenif Site). The groundwater occurs in Digma and Tayarat carbonate rocks, while the unsaturation zone represented by stratigraphic layers of Akashat and Rattga Formations.

-District of Muhaywir and Ubaid aquifer (D5): The district of $2730 \mathrm{~km}^{2}$ is located at the east part of the district (D3). The groundwater exists in the water bearing horizons of Ubaid and Muhaywir Formations. The stratigraphic layers of Maudod, Rutba, and Msad Formations represent the unsaturated zone.

-District of Ubaid-Mullusi aquifer (D6): The district area is about $1365 \mathrm{~km}^{2}$, situated to the east of district (D2). The groundwater exists in Ubaid-Mullusi water bearing horizons. The layers of Maudod and Husayniyat Formations composed the zone of unsaturation.

-District of Rattga and Digma-Tayarat aquifers (D7): The district area of about $3900 \mathrm{~km}^{2}$ is located in the northern part within Swab and Akashat basins. The groundwater exists in Digma-Tayarat carbonate rocks and in Rattga Formation as perched water. The unsaturation zone comprises recent sediments and some layers of Rattga Formation.

-District of Digma-Tayarat aquifer (D8): The district area is $1950 \mathrm{~km}^{2}$, located at the NE portion. The groundwater exists in Digma and Tayarat Formations, while the unsaturation zone obtains the layers of Rattga and Nefile Formations.

\subsection{Boundary Conditions of Aquifers}

The boundary conditions of aquifers are summarized according to the thickness and extension of water bearing horizons, as follows:

1-Ga'ra Aquifer: The aquifer of static water level ranged between $420 \mathrm{~m}$ asl and $470 \mathrm{~m}$ asl [50] is recharged from the scope of Rutba Uplift lands along Rattga Valley and its tributaries and from lateral leakage of waters passing from adjacent aquifers having a hydraulic head more than $470 \mathrm{~m}$ asl, especially from the western parts. The water bearing horizons influenced by structural setting of the area resulted from Rutba uplift process, which gives an unconfined to semi confined conditions for shallow aquifer and confined condition for the deep water bearing horizons. The aquifer characterized by large extensions and Figure 7 explains the model of Ga'ra Aquifer extension in three dimensions.

2-Mullusi Aquifer: Mullusi aquifer is recharged from the scope of Rutba Uplift lands along Hauran Valley and its tributaries which represent the groundwater divide after water penetration through the uppermost geological layers. Mullusi aquifer is of semi-confined condition [51]. The water bearing horizons influenced by Rutba uplift process (branch of Hail arc), which creating dip in layers in different direction surrounding uplift. Mullusi aquifer characterized by large extensions and its thickness reaches $100 \mathrm{~m}$ in the south definitely in Abu Menttar, 130 meters in Amij and northerly wedge out in Ga'ra depression at 30 meters thick. Figure 7 explains the model of Mullusi Aquifer extension in three dimensions.

3-Ubaid Aquifer: The aquifer is recharged from the drainage basins of Hauran and Hussayniyat Valleys in which Ubaid layers were exposed, creating boundaries of unconfined to semi-confined conditions [41].

The thickness of Ubaid water bearing horizons is influenced by paleo stratigraphic and structural settings, where Ubaid carbonate layers formed part of geologic sequences in Rutba Uplift zone. The thickness of Ubaid carbonates aquifer within its extension in district (D6) ranges between 44 and $80 \mathrm{~m}$.

4-Muhaywir Aquifer: The aquifer is recharged from its exposure zone within Amij catchment area. The aquifer is cha racterized by semi confined storage condition within district (D5), which gradually changes to con- 


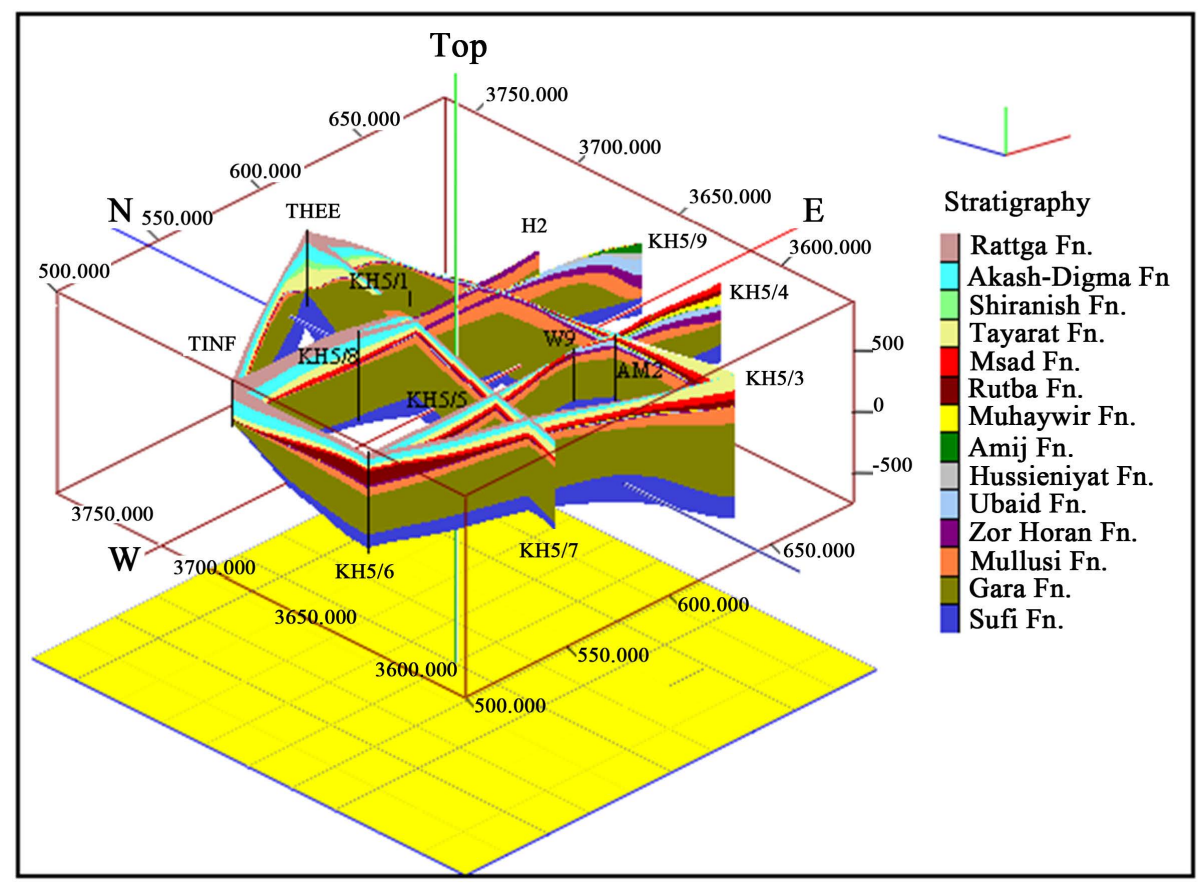

Figure 7. Lateral and vertical extension model of water bearing formations within study area.

fined aquifer in the south eastern parts. The thickness of aquifer including sandstone and carbonate beds is ranged from $40 \mathrm{~m}$ to $96 \mathrm{~m}$. The extension of the aquifer is shown in (Figure 7).

5-Hartha Aquifer: The aquifer was fed by water from of Ghadaf catchment area including Hazimi tributary and from lateral leakage of waters passing from Tayarat-Digma aquifer in the western parts (Figure 6). The aquifer characterized by semi confined to confined storage condition with a thickness of about 130 meters in the east part of district (D3).

6-Tayarat-Digma Aquifer: It is unconfined aquifer of wide extension in Tenif and Swab sites (district D4 and D7), with a thickness of carbonate aquifer ranged between $140 \mathrm{~m}$ and $180 \mathrm{~m}$ intra-regional of Tenif and Swab. This aquifer characterized by confined storage condition in a thickness ranged from 36 to $122 \mathrm{~m}$ within Muger Elthib Site.

7-Rattga Aquifer: The aquifer is of perched unconfined condition in the interiors area of Swab drainage basin within district (D7). The thickness of Rattga aquifer ranged from $100 \mathrm{~m}$ to $138 \mathrm{~m}$.

\subsection{Groundwater Recharge and Infiltration Rate}

Study of [22] in its part-1 indicates that the available groundwater resources in Al Hamad zone are originated to old source. The recharge is mainly happened during southern pluvial period (late Pleistocene age) of high frequency precipitation dated back to more than 30,000 Years BP, and followed by northern pluvial period (early Holocene) of second frequency precipitation that continued during 15,000 and 22,000 Years BP. Then the third pluvial period (of third order frequency) continued between 6000 to 14,000 Years BP. Finally, the fourth lowest pluvial period (Neolithic period) is of $<5000$ Years BP. These results are confirmed through analysis of isotopes elements $\left({ }^{14} \mathrm{C},{ }^{3} \mathrm{H},{ }^{13} \mathrm{C}\right.$ and $\left.{ }^{18} \mathrm{O}\right)$ [52]. Al Hamad physiographic zone is considered as a main recharge zone of the aquifers within study area, [37] [41] [53], just as these studies confirmed a practical occurrence of recharge and water replenishment renewed aquifers by rain and runoff waters penetrated throughout rocks exposures within the valleys, Hauran, Ghadaf, Alwalaj, Swab and Rattga. The recharge inflow is also, done as a result of hydraulic connection between aquifers. The infiltration rate (Rnp) that penetrated to the groundwater in the study area is equal to $4.9 \%$ from the mean annual value of rainfall calculated from regional water balance study of Iraq [54]. Accordingly, and on the basis of mean annual rainfall (PPT $=106.9 \mathrm{~mm} /$ year) of the study area, therefore the amount of infiltration rate becomes $5.24 \mathrm{~mm} /$ year using the equation of;

Infiltrate Rate $=$ Rnp $\times$ PPT, While the amount of water infiltration is calculated by the following equation: 
Amount of infiltration $=$ infiltration rate $\times$ area

Amount of infiltration to all aquifers $=0.00524(\mathrm{~m} /$ year $) \times 170.44 \times 10^{8} \mathrm{~m}^{2}=204.36 \times 10^{6} \mathrm{~m}^{3} /$ year.

Therefore, the amount of renewal water that entered each aquifer is as following:

-Ga'ra aquifer in district- $1=28.61 \times 10^{6} \mathrm{~m}^{3} /$ year.

-Mullusi aquifer in district- $2=72.57 \times 10^{6} \mathrm{~m}^{3} /$ year.

-Hartha aquifer in district-3 $=24.52 \times 10^{6} \mathrm{~m}^{3} /$ year.

-Tayarat-Digma aquifer in district- $4=26.57 \times 10^{6} \mathrm{~m}^{3} /$ year.

-Muhaywir-Ubaid aquifer in district-5 $=14.3 \times 10^{6} \mathrm{~m}^{3} /$ year.

-Mullusi-Ubaid aquifer in district- $6=7.15 \times 10^{6} \mathrm{~m}^{3} /$ year.

-Rattga and Jeed aquifer in district-7 $=20.43 \times 10^{6} \mathrm{~m}^{3} /$ year.

-Tayarat-Digma aquifer in district-8 $=10.21 \times 10^{6} \mathrm{~m}^{3} /$ year.

\subsection{Hydraulic Parameters}

The evaluation of the aquifer characteristics are determined according to the available hydraulic information collected from previous hydrogeologic studies [20]-[22] [51]. The permeability of aquifers within district-1, 2, 3, 4, 5, 6, 7 and 8 ranged from 0.0078 to $2.01 \mathrm{~m} /$ day, 0.0078 to $3.01 \mathrm{~m} /$ day, 0.1 to $1.3 \mathrm{~m} /$ day, 0.2 to $1.51 \mathrm{~m} /$ day, 0.5 to $1.01 \mathrm{~m} /$ day, 0.1 to $3.51 \mathrm{~m} /$ day, 0.51 to $4.51 \mathrm{~m} /$ day and from 0.2 to $4.1 \mathrm{~m} /$ day respectively (Table 2). Those aquifers are classified as aquifers of low permeability compared with Laboutka classification [55], (Table 4).

The variation in the values of permeability originated to the heterogeneity of the rocks forming aquifers, density of fractures and joints. Spatial distribution map of permeability (Figure 8), shows increasing in permeability grade varies between 0.0000002 and $0.0009 \mathrm{~m} /$ day/meter distance towards Digma-Tayarat aquifer and its extensions with Rattga aquifer in district-7 and also, increases within Ubaid-Mullusi aquifer, whereas the permeability values decrease in the other aquifers, specifically in Hartha aquifer, Ubaid-Muhaywir aquifer and Mullusi aquifer in Traybil site.

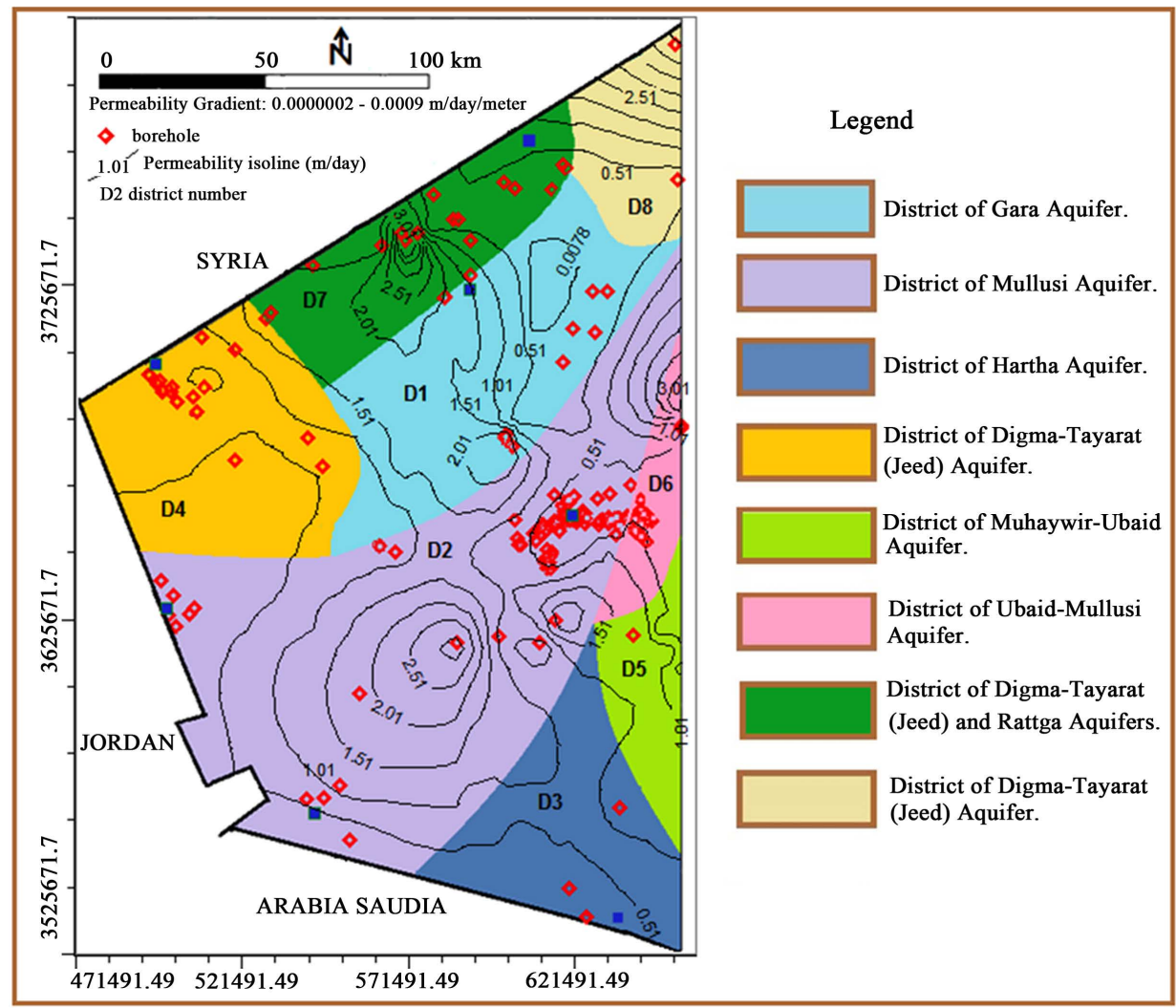

Figure 8. Spatial variation map of permeability. 
Table 4. Laboutka classification of hydraulic parameters.

\begin{tabular}{ccccc}
\hline Class & Discharge $\mathrm{m}^{3} /$ day & Specific capacity $\mathrm{m}^{3} /$ day $/ \mathrm{m}$ & Transmissivity $\mathrm{m}^{2} /$ day & Permeability $\mathrm{m} /$ day \\
\cline { 1 - 3 } Very high & $>2160$ & $>864$ & $>950$ & $>864$ \\
high & $432-2160$ & $86.4-864$ & $95-950$ & $86.4-864$ \\
middle & $432-43.2$ & $8.64-86.4$ & $9.5-95$ & $8.64-86.4$ \\
low & $<43.2$ & $<8.64$ & $<9.5$ & $<8.64$ \\
\hline
\end{tabular}

Permeability values of aquifers within eight districts and their frequency percent (Fs\%) plotted on probability-logarithm paper, where frequency percent $(\mathrm{Fs} \%)=\left[\mathrm{M}_{0} /(\mathrm{NW}+1)\right] \times 100, \mathrm{M}_{0}$; rank number, $\mathrm{N}_{\mathrm{w}}$; total number of wells [25] [56] [57].

The comparison of the results of permeability as derived from statistical interpretation (Figure 9) indicated by wells percent of $30 \%, 50 \%$ and $90 \%$ (Table 5), shows that the possibility of getting high permeability values are within the probability of wells $50 \%$ to $90 \%$, as in the following descending order of aquifers.

Rattga and Digma-Tayarat aquifer within district-7, Digma-Tayarat aquifer within district-4, Ubaid-Mullusi aquifer within district-6, Hartha aquifer within district-3, Mullusi aquifer within district-2, Digma-Tayarat within district-8, Ga'ra aquifer within district-1 and Muhaywir-Ubaid aquifer within district-5.

The transmissivity coefficient of Ga'ra aquifer(D1), Mullusi aquifer(D2), Hartha aquifer(D3), Digma-Tayarat aquifer (D4), Muhaywir-Ubaid aquifer (D5), Ubaid-Mullusi aquifer (D6), Rattga and Digma-Tayarat aquifer (D7), and Digma-Tayarat aquifer (D8) varies from 60 to $240.8 \mathrm{~m}^{2} / \mathrm{day}, 0.8$ to $632 \mathrm{~m}^{2} / \mathrm{day}, 4$ to $200 \mathrm{~m}^{2} / \mathrm{day}, 5$ to $250 \mathrm{~m}^{2} /$ day, 60 to $180 \mathrm{~m}^{2} /$ day, 5 to $60.8 \mathrm{~m}^{2} /$ day, 60 to $120.8 \mathrm{~m}^{2} /$ day and from 60.4 to $360.8 \mathrm{~m}^{2} /$ day, respectively, (Table 2). The aquifers within the Districts are classified as aquifers of middle to high transmissivity comparing with Laboutka classification (Table 4), while the aquifers within the Districts D2, D3, D4 and D6 are of low to high class. Spatial distribution map of transmissivity (Figure 10), shows limited correspondence with the distribution of permeability. There is an increasing in transmissivity variation grade ranged between 0.00004 and 0.06 $\mathrm{m}^{2} / \mathrm{day} / \mathrm{m}$ within the zone of Mullusi aquifer (Hauran catchment area) and the zone of Digma-Tayarat aquifer in Rattga catchment area, whereas the transmissivity value decreases within Swab and Alwalaj basins and in Muger Elnaam region (southeast of study area). Eight groups of transmissivity values and their frequency percent (Fs \%) for the aquifers are plotted on probability-logarithm paper, where frequency percent $(\mathrm{Fs} \%)=\left[\mathrm{M}_{0} /(\mathrm{NW}+\right.$ $1)] \times 100, \mathrm{M}_{0}$; rank number, $\mathrm{N}_{\mathrm{w}}$; total number of wells. The comparison of the transmissivity results as derived from statistical interpretation indicated by wells percent of 30\%, 50\% and 90\% (Table 6), shows that the possibility of getting high transmissivity coefficient are within the probability of wells percent ranged between $50 \%$ to $90 \%$, as follows:

Digma-Tayarat aquifer within district-4, Ga'ra aquifer within district-1, Muhaywir-Ubaid aquifer within district-5, Digma-Tayarat within district-8, Hartha aquifer within district-3, Rattga and Digma-Tayarat aquifer within district-7, Mullusi aquifer within district-2 and Ubaid Mullusi aquifer within district-6.

The groundwater of Ga'ra aquifer within district-1, Hartha aquifer within district-3, Muhaywir-Ubaid aquifer within district-5, Ubaid Mullusi aquifer within district-6 Digma-Tayarat within district-8 are controlled by unconfined to semi confined conditions, where the average of storativity for these aquifers are $8.8 \times 10^{-3}, 1.15 \times$ $10^{-2}, 1.8 \times 10^{-2}, 1.46 \times 10^{-2}$ and $9.2 \times 10^{-3}$ respectively. While the groundwater of Mullusi aquifer within district-2, Digma-Tayarat aquifer within district-4 and Rattga-Jeed aquifers in district-7 are controlled by semi confined to confined storage conditions, with a storativity of $5 \times 10^{-3}, 6.4 \times 10^{-3}$ and $4.4 \times 10^{-3}$ respectively, (Table 2).

Spatial distribution map of storativity (Figure 11), shows an increasing in storage variation grade ranged between $10^{-6}$ /meter and $10^{-10}$ /meter of distance within the zone of Mullusi aquifer and Muhaywir-Ubaid aquifer in Hauran catchment area and the zone of Digma-Tayarat aquifer in Rattga catchment area, whereas the storativity value decreases in aquifers within Swab and Alwalaj basins, also in Takhadid area in the south west direction. Eight groups of storativity and their frequency percent (Fs \%) for aquifers are plotted on probability-logarithm paper. The comparison of the storativity results as derived from statistical probability interpretation indicated by wells percent of 30\%, 50\% and 90\% (Table 7), shows that the possibility of getting high storativity are within the probability of wells percent ranged between $50 \%$ to $90 \%$, as follows: Ubaid Mullusi aquifer within district-6, Hartha aquifer within district-3, Muhaywir-Ubaid aquifer within district-5, Digma-Tayarat within district-8, 


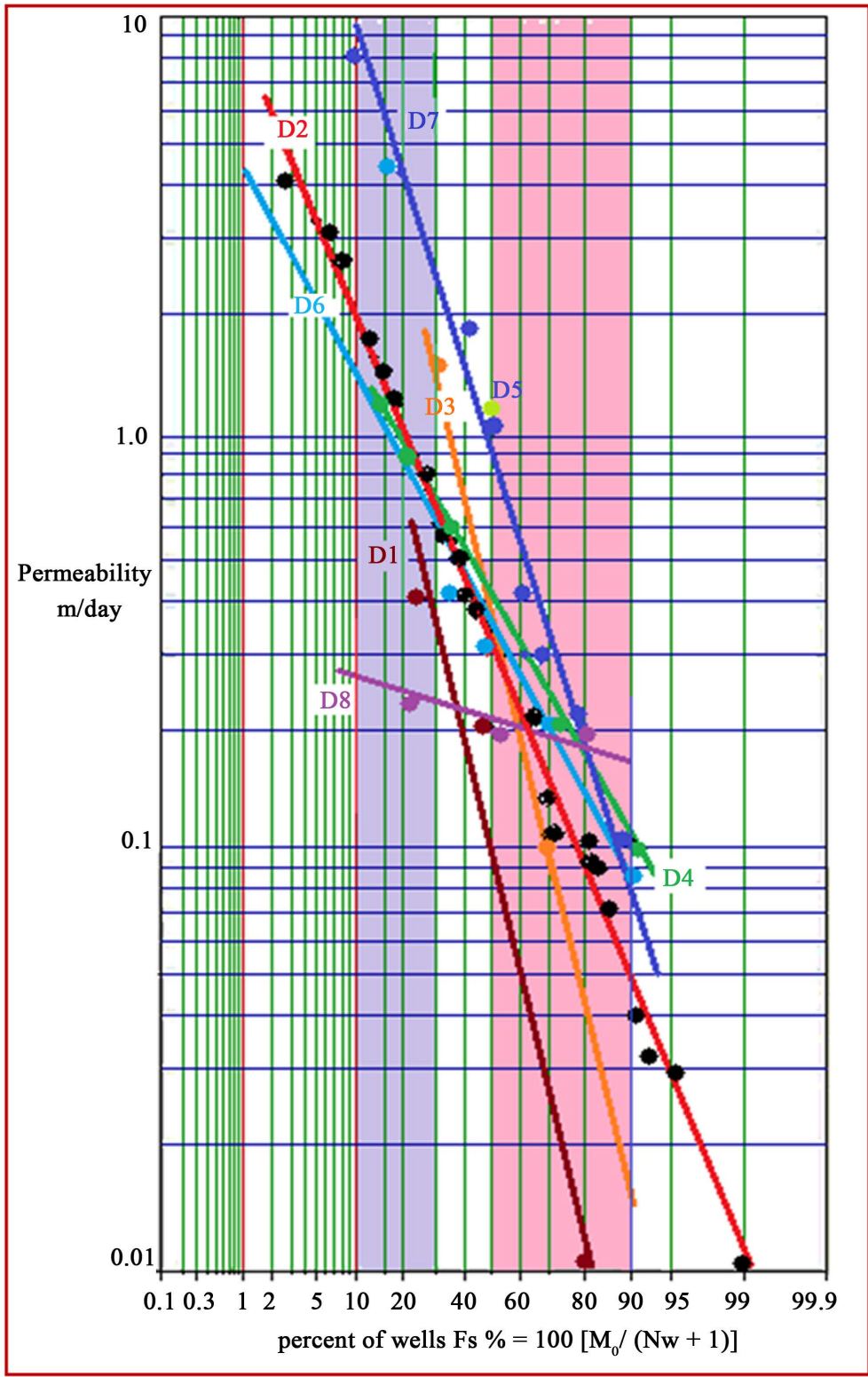

Figure 9. Permeability frequency graphs of aquifers.

Table 5. Permeability and wells percent of aquifers.

\begin{tabular}{cccc}
\hline Aquifer & $\begin{array}{c}\text { Permeability }\left(\mathrm{m}^{2} / \mathrm{d}\right) \\
\text { at wells percent of } 30 \%\end{array}$ & $\begin{array}{c}\text { Permeability }\left(\mathrm{m}^{2} / \mathrm{d}\right) \\
\text { at wells percent of } 50 \%\end{array}$ & $\begin{array}{c}\text { Permeability }\left(\mathrm{m}^{2} / \mathrm{d}\right) \\
\text { at wells percent of } 90 \%\end{array}$ \\
\hline Ga'ra Aquifer. D1 & 0.45 & 0.13 & 0.0045 \\
Mullusi-Aquifer. D2 & 0.7 & 0.3 & 0.03 \\
Hartha Aquifer. D3 & 1.7 & 0.4 & 0.012 \\
Digma-Tayarat Aquifers. D4 & 0.8 & 0.46 & 0.1 \\
Muhaywir-Ubaid Aquifer. D5 & $/$ & 1.2 & $/$ \\
Ubaid-Mullusi Aquifer. D6 & 0.8 & 0.4 & 0.074 \\
Rattga-Digma-Tayarat Aq. D7 & 1.7 & 0.7 & 0.09 \\
Digma-Tayarat. D8 & 0.24 & 0.21 & 0.17 \\
\hline
\end{tabular}




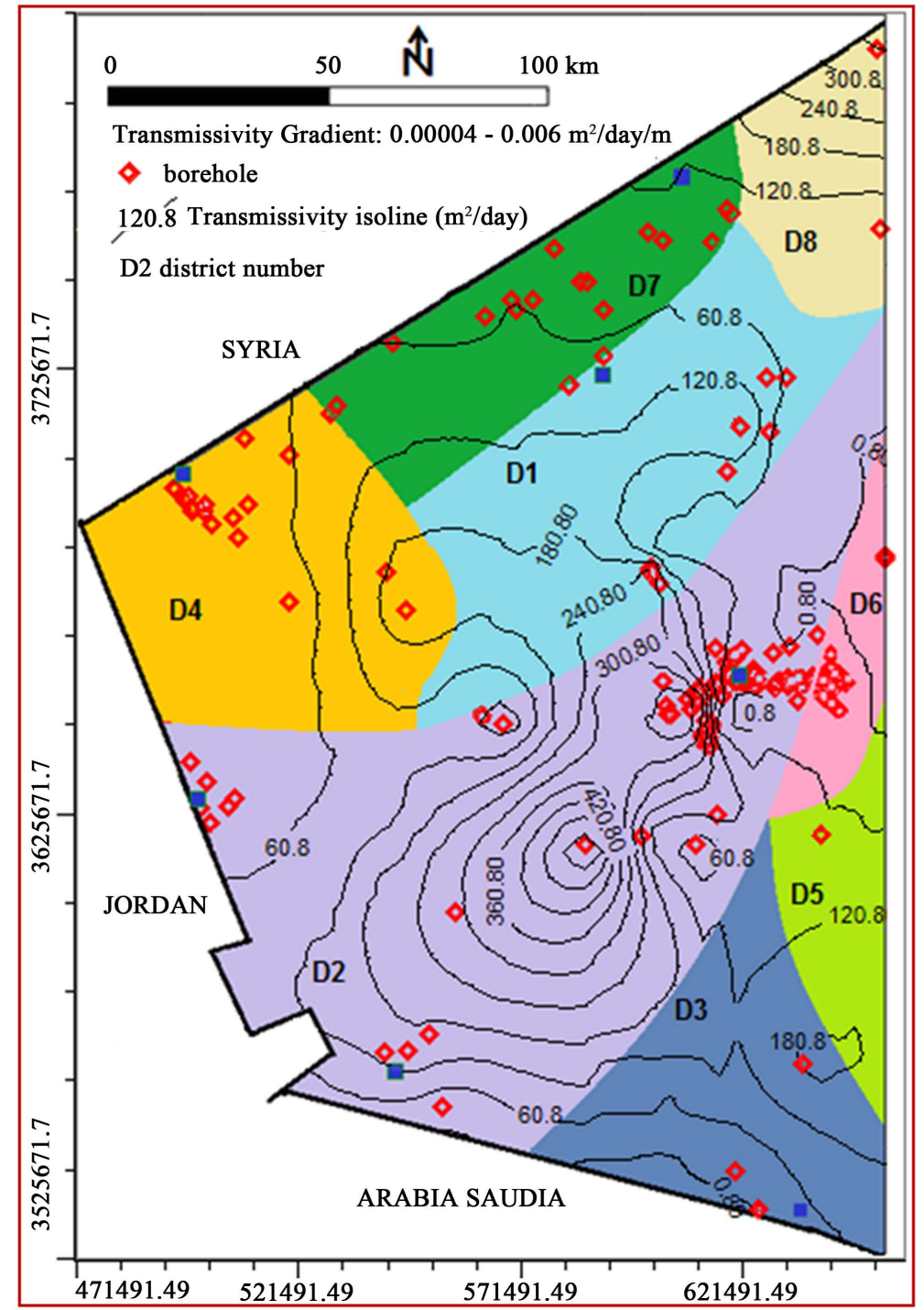

Figure 10. Distribution model of transmissivity.

Table 6. Frequency and transmissivity of the aquifers.

\begin{tabular}{cccc}
\hline Aquifer & $\begin{array}{c}\text { Transmissivity }\left(\mathrm{m}^{2} / \mathrm{d}\right) \\
\text { at wells percent of } 30 \%\end{array}$ & $\begin{array}{c}\text { Transmissivity }\left(\mathrm{m}^{2} / \mathrm{d}\right) \\
\text { at wells percent of } 50 \%\end{array}$ & $\begin{array}{c}\text { Transmissivity }\left(\mathrm{m}^{2} / \mathrm{d}\right) \\
\text { at wells percent of } 90 \%\end{array}$ \\
\hline $\begin{array}{c}\text { Ga'ra Aquifer. D1 } \\
\text { Mullusi Aquifer. D2 }\end{array}$ & 700 & 100 & 6.3 \\
Hartha Aquifer. D3 & 190 & 23 & 2.4 \\
Digma-Tayarat Aquifer. D4 & 140 & 51 & 1.7 \\
Muhaywir-Ubaid Aquifer. D5 & $/$ & 65 & $/$ \\
Ubaid-Mullusi Aquifer. D6 & 12 & 75 & 0.6 \\
Rattga-Digma-Tayarat Aquifers.D7 & 72 & 5 & 5 \\
Digma-Tayarat Aquifer. D8 & 200 & 36 & 2.8 \\
\hline
\end{tabular}




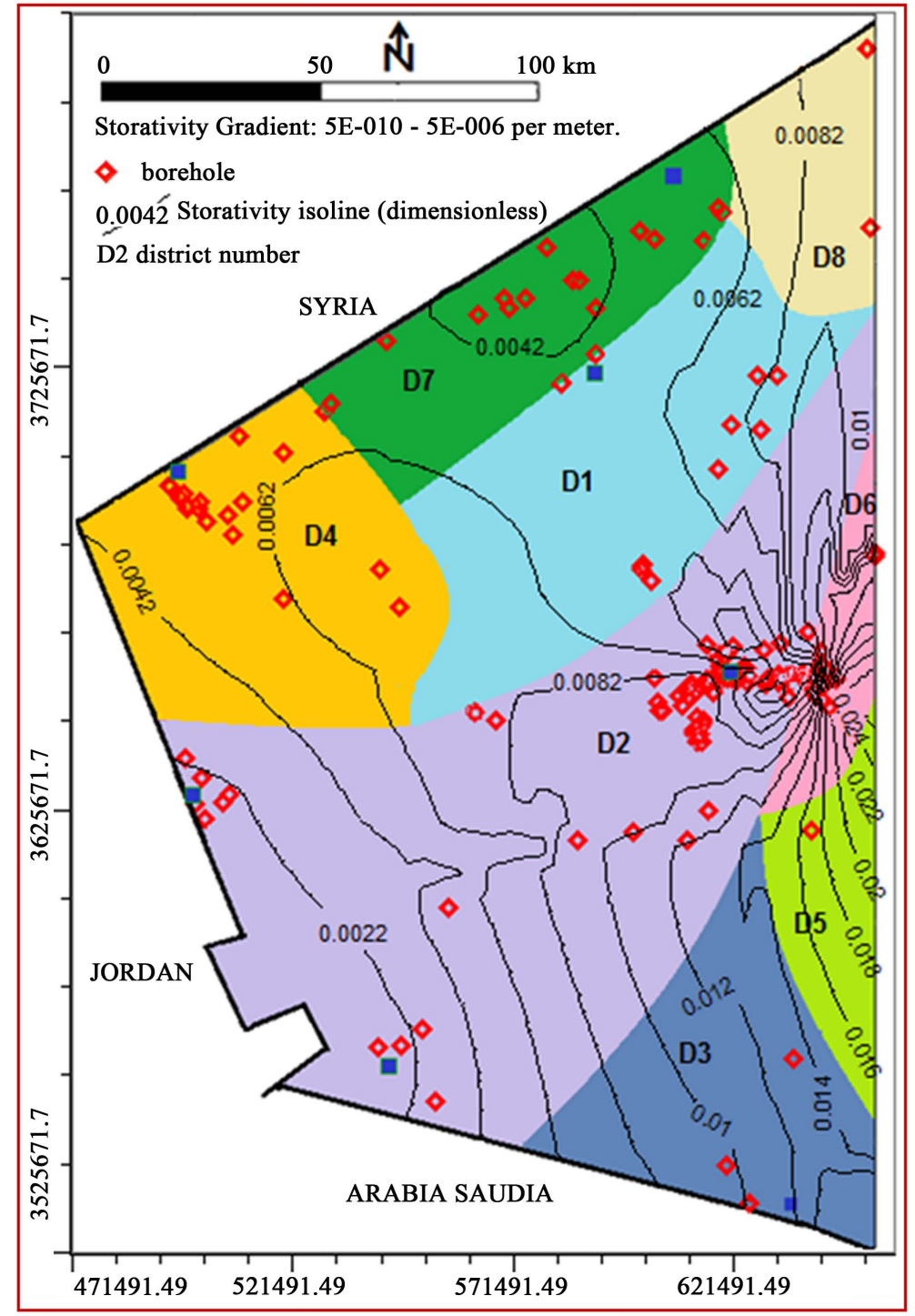

Figure 11. Distribution map of storativity.

Table 7. Frequency and storativity of the aquifers.

\begin{tabular}{cccc}
\hline Aquifer & $\begin{array}{c}\text { Storativity at wells } \\
\text { percent of 30\% }\end{array}$ & $\begin{array}{c}\text { Storativity at wells } \\
\text { percent of 50\% }\end{array}$ & $\begin{array}{c}\text { Storativity at } \\
\text { wells percent of } 90 \%\end{array}$ \\
\hline Ga'ra Aquifer. D1 & 0.0091 & 0.0089 & 0.0078 \\
Mullusi Aquifer. D2 & 0.006 & 0.0028 & 0.00036 \\
Hartha Aquifer. D3 & 0.013 & 0.011 & 0.0085 \\
Digma-Tayarat Aquifer. D4 & 0.0072 & 0.0065 & 0.0048 \\
Muhaywir-Ubaid Aquifer. D5 & $/$ & 0.017 & $/$ \\
Ubaid-Mullusi Aquifer. D6 & 0.018 & 0.015 & 0.008 \\
Rattga-Digma-Tayarat Aquifer. D7 & 0.0045 & 0.004 & 0.003 \\
Digma-Tayarat. D8 & 0.01 & 0.009 & 0.008
\end{tabular}


Ga'ra aquifer within district-1, Digma-Tayarat aquifer within district-4, Mullusi aquifer within district-2 and Rattga and Digma-Tayarat aquifer within district-7.

\subsection{Specific Capacity of Wells}

The specific capacity of the water wells penetrated Ga'ra aquifer within district-1, Mullusi aquifer within district-2, Hartha aquifer within district-3, Digma-Tayarat aquifer within district-4, Ubaid-Muhaywir aquifer within district-5, Ubaid Mullusi aquifer within district-6, Rattga-Jeed aquifer within district-7 and Digma-Tayarat within district-8 ranged between 32.19 and $107.2 \mathrm{~m}^{3} /$ day/m, between 2.9 and 92.19 , between 17.1 and 44 , between 22 and 51.2, between 11.2 and 24.6, between 6.62 and 62.1, between 4.96 and 77.99 and from 48 to158.4 $\mathrm{m}^{3} /$ day/m, respectively, (Table 2).

The distribution map of the specific capacity (Figure 12), confirmed that there is a spatial variation as increasing grade ranged between 0.00001 and $0.0118 \mathrm{~m}^{3} / \mathrm{day} / \mathrm{m}$ of drawdown $/ \mathrm{m}$ of distance towards wells of (Gar'a aquifer in district-1 and Digma-Tayarat aquifer in district-8) in high category of specific capacity compared with Laboutka classification, while it decreases to low and medium category of specific capacity classification in the other part. Statistical method is used in comparison of specific capacity values within aquifers for the purpose of define which aquifer has the large impact on the productivity of wells from mixed aquifers.

Eight groups of specific capacity values and their frequency percent (Fs \%) for the aquifers are plotted on probability-logarithm paper. The comparison of specific capacity results as derived from statistical probability interpretation indicated by wells percent of 30\%, 50\% and 90\% (Table 8), shows that the possibility of getting high values of specific capacity are within the probability of wells percent ranged between $50 \%$ to $90 \%$, as fol-

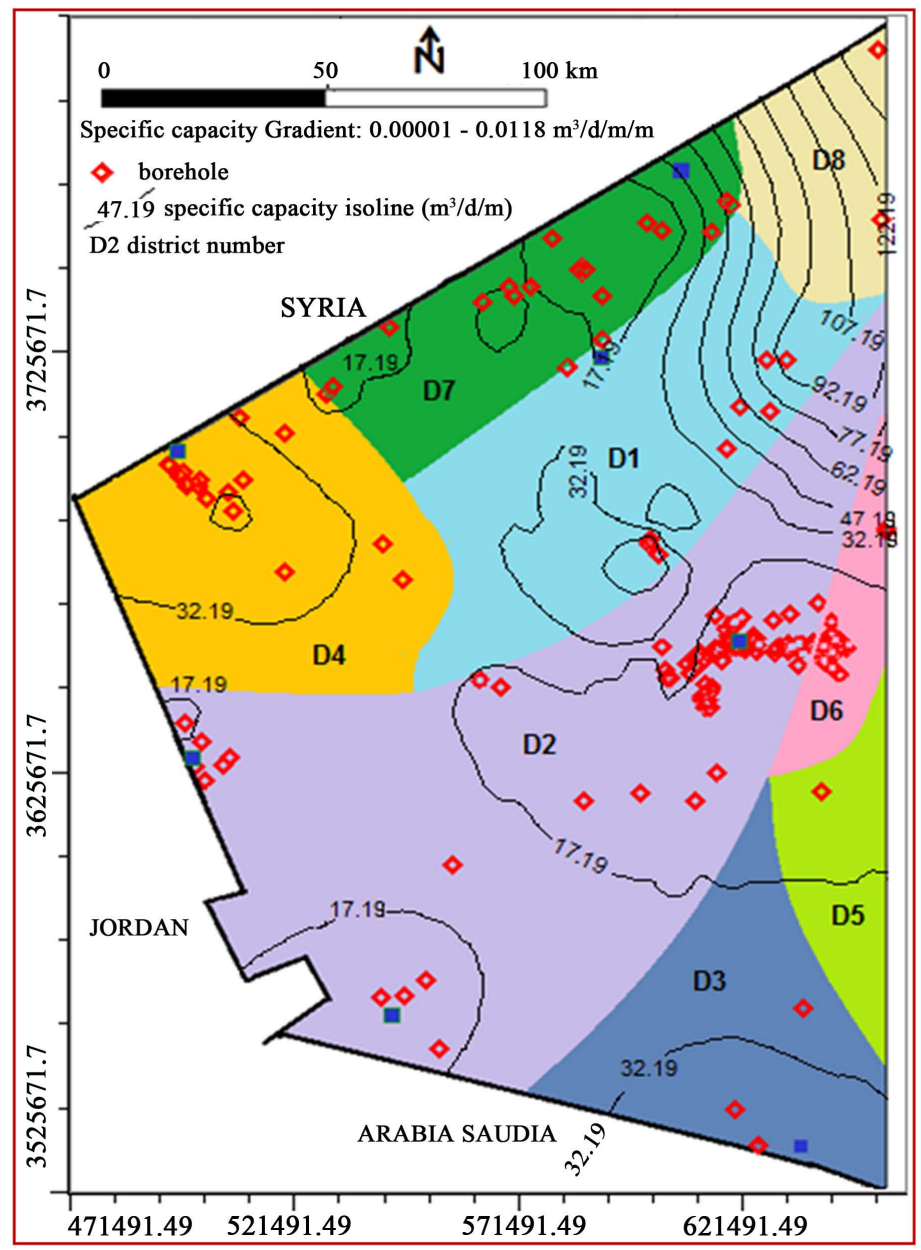

Figure 12. Spatial distribution map of specific capacity. 
Table 8. Frequency and specific capacity.

\begin{tabular}{cccc}
\hline Aquifer & $\begin{array}{c}\text { Specific capacity }\left(\mathrm{m}^{3} / \mathrm{d} / \mathrm{m}\right) \\
\text { at wells percent of } 30 \%\end{array}$ & $\begin{array}{c}\text { Specific capacity }\left(\mathrm{m}^{3} / \mathrm{d} / \mathrm{m}\right) \\
\text { at wells percent of } 50 \%\end{array}$ & $\begin{array}{c}\text { Specific capacity }\left(\mathrm{m}^{3} / \mathrm{d} / \mathrm{m}\right) \\
\text { at wells percent of } 90 \%\end{array}$ \\
\hline Ga'ra Aquifer. D1 & 100 & 80 & 50 \\
Mullusi Aquifer. D2 & 13 & 8.5 & 3.8 \\
Hartha Aquifers. D3 & 45 & 31 & 13 \\
Digma-Tayarat Aquifer. D4 & 42 & 36 & 21 \\
Muhaywir-Ubaid Aquifer. D5 & $/$ & 11 & 4.9 \\
Ubaid-Mullusi Aquifer. D6 & 30 & 18 & 4 \\
Rattga-Digma-Tayarat Aquifer. D7 & 20 & 12 & 40 \\
Digma-Tayarat. D8 & 145 & 110 & \\
\hline
\end{tabular}

lows: Digma-Tayarat in district-8, Ga'ra aquifer within district-1, Digma-Tayarat aquifer within district-4, Hartha aquifer within district-3, Ubaid Mullusi aquifer within district-6, Rattga and Digma-Tayarat aquifer within district-7, Muhaywir-Ubaid aquifer within district-5 and Mullusi aquifer within district-2.

\subsection{Groundwater Depth}

The groundwater depths of the aquifers within district-1, 2, 3, 4, 5, 6, 7 and 8 are ranged from 58 to 197 meters, 26 to 399 meters, 104 to 46 meters, 194 to 309 meters, 85 to 295 m, 15 to 295 meters, 36 to 216 meters and from 70 to 86 meters, respectively. The distribution map of the groundwater depths (Figure 13), indicated that there is a spatial variation as increasing grade ranged between 0.00006 and 0.04 meter of groundwater depth per meter of distance towards aquifers located at the west and south western portions of the study area.

The comparison of groundwater depth results as derived from statistical probability interpretation indicated by wells percent of $30 \%, 50 \%$ and $90 \%$ (Table 9), confirmed that the possibility of getting shallow groundwater are within the probability of wells percent ranged between $50 \%$ to $90 \%$, as follows: Ubaid Mullusi aquifer (D6), Digma-Tayarat (D8), Ga'ra aquifer (D1), Mullusi aquifer (D2), Rattga and Digma-Tayarat aquifer within (D7), Muhaywir-Ubaid aquifer (D5), Digma-Tayarat aquifer (D4) and Hartha aquifer (D3).

\subsection{Acidity of Groundwater}

The groundwater acidity $(\mathrm{pH})$ of the aquifers within district-1, 2, 3, 4, 5, 6, 7 and 8 are ranged from 7.1 to 7.69 , 7.1 to $8.2,7.2$ to $7.46,7.0$ to $7.6,6.9$ to $7.58,6.9$ to $7.9,7.1$ to 8.1 and from 7.0 to 7.6 , respectively. The comparison of $\mathrm{pH}$ results as derived from statistical probability interpretation indicated by wells percent of $30 \%, 50 \%$ and 90\% (Table 10), shows low variation of $\mathrm{pH}$, classified as neutral water [58] in all aquifers, means all aquifers have same ranking chance to be selected for exploitation.

\subsection{Total Dissolve Solids (TDS)}

The groundwater salinity (Concentration of TDS) within district-1, 2, 3, 4, 5, 6, 7 and 8 are ranged from 804 to $3816 \mathrm{mg} / \mathrm{l}, 804$ to $5920 \mathrm{mg} / \mathrm{l}, 450$ to $1346 \mathrm{mg} / \mathrm{l}, 1050$ to $2843 \mathrm{mg} / \mathrm{l}, 611$ to $1304 \mathrm{mg} / \mathrm{l}, 803$ to $5399 \mathrm{mg} / \mathrm{l}, 800$ to $1453 \mathrm{mg} / \mathrm{l}$ and from 1072 to $2338 \mathrm{mg} / \mathrm{l}$, respectively. The groundwater is classified as fresh to slightly saline water according to TDS classification in [15] [58]-[60].

Distribution map of TDS (Figure 14), shows increase of concentration in an enrichment grade of 0.00045 to $1.046 \mathrm{mg} / \mathrm{liter} / \mathrm{m}$ to the NW portion (within district-6 and western part of district-2) and to the north east direction (district-8) corresponding with the flow direction, while TDS values decrease in the catchment area of Swab and Hauran valleys which represent the zone of infiltration and source of groundwater replenishment.

The comparison of TDS results as derived from probability-logarithm interpretation indicated by wells percent of 30\%, 50\% and 90\% (Table 11), illustrates the probability of getting fresh water (TDS concentration less than $1000 \mathrm{mg} / \mathrm{l})$ from various aquifers. Accordingly, the groundwater of best quality can be exploited from the following aquifers, where these aquifers are listed in descending order, initiated firstly by high probability percentile.

1-Rattga and Digma-Tayarat aquifer within district-7.

2-Mullusi aquifer within district-2. 


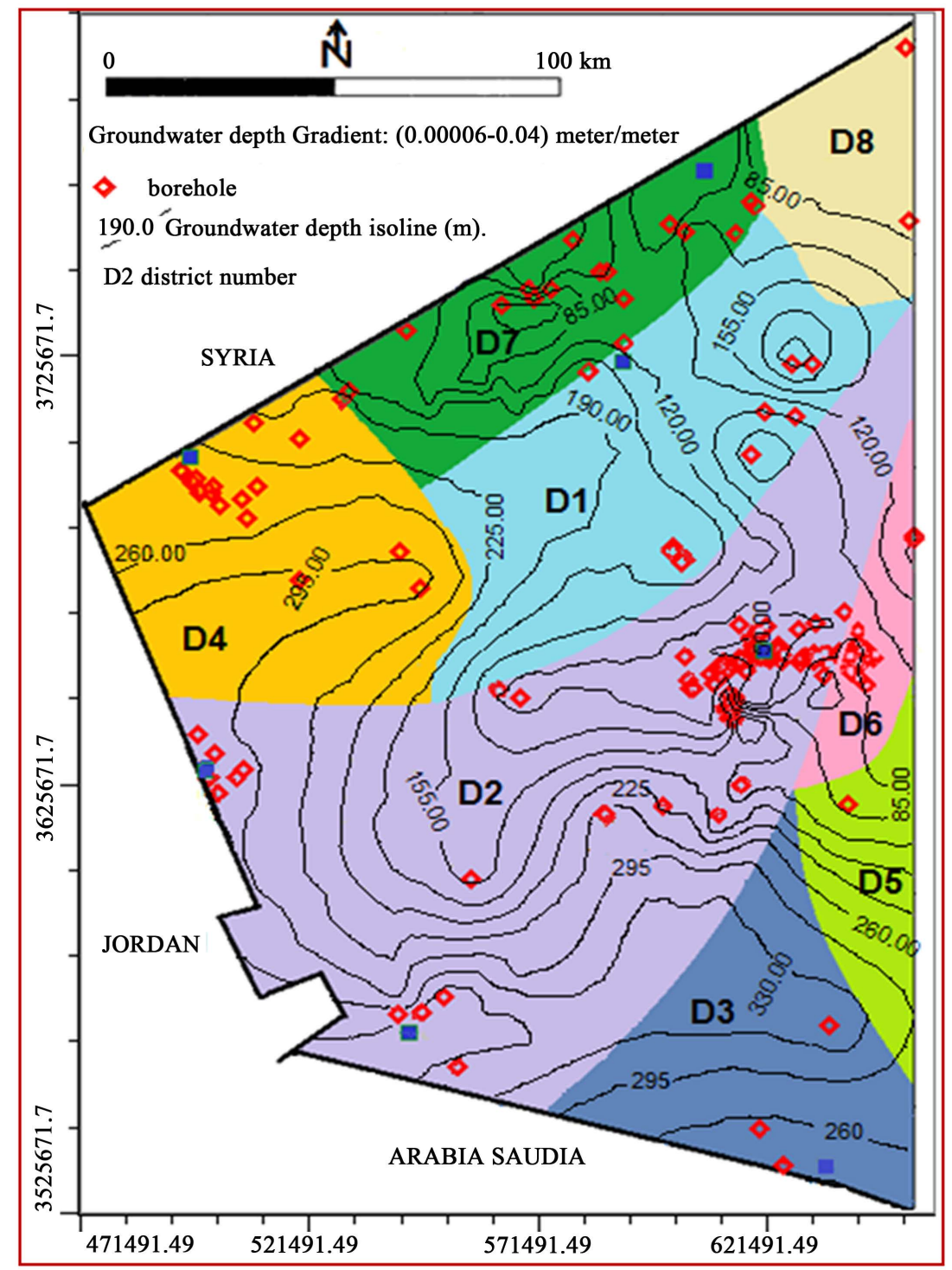

Figure 13. Distribution map of the groundwater depths.

Table 9. Frequency and groundwater depth.

\begin{tabular}{cccc}
\hline Aquifer & $\begin{array}{c}\text { Groundwater depth }(\mathrm{m}) \\
\text { at wells percent of } 30 \%\end{array}$ & $\begin{array}{c}\text { Groundwater depth (m) } \\
\text { at wells percent of 50\% }\end{array}$ & $\begin{array}{c}\text { Groundwater depth (m) } \\
\text { at wells percent of } 90 \%\end{array}$ \\
\hline Ga'ra Aquifer. D1 & 150 & 110 & 58 \\
Mullusi Aquifer. D2 & 160 & 120 & 45 \\
Hartha Aquifer. D3 & 490 & 250 & 200 \\
Digma-Tayarat Aquifers. D4 & 260 & 240 & $/$ \\
Muhaywir-Ubaid Aquifer. D5 & $/$ & 225 & 38 \\
Ubaid-Mullusi Aquifer. D6 & 75 & 60 & 60 \\
Rattga-Digma-Tayarat Aquifer. D7 & 170 & 120 & 58 \\
Digma-Tayarat. D8 & 88 & 78 & 36 \\
\hline
\end{tabular}




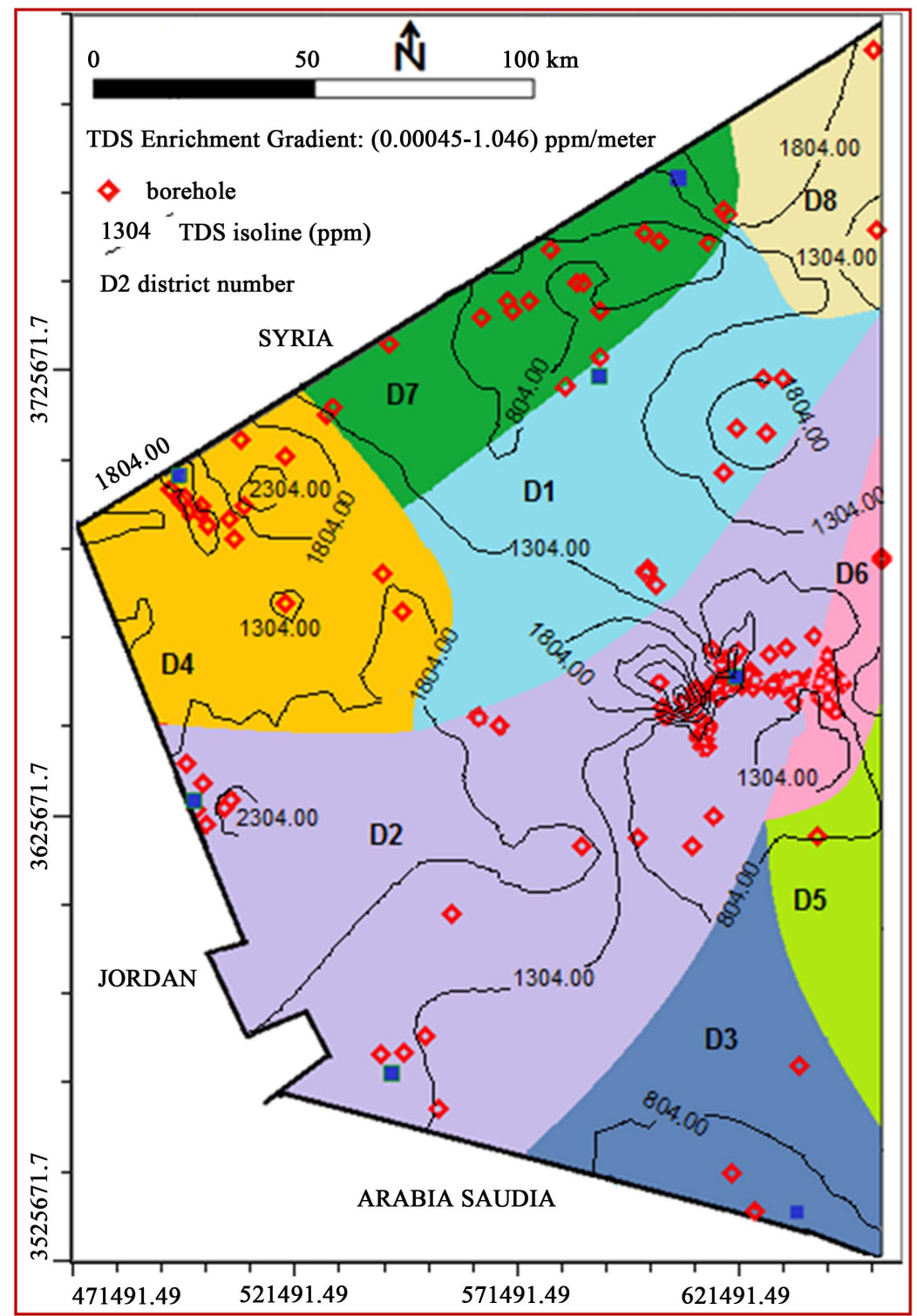

Figure 14. Spatial distribution map of groundwater salinity (TDS).

Table 10. Frequency and groundwater $\mathrm{pH}$ of the aquifers.

\begin{tabular}{cccc}
\hline Aquifer & $\mathrm{pH}$ at wells percent of 30\% & $\mathrm{pH}$ at wells percent of $50 \%$ & $\mathrm{pH}$ at wells percent of $90 \%$ \\
\hline Ga'ra Aquifer. D1 & 7.8 & 7.5 & 7.0 \\
Mullusi Aquifer. D2 & 7.95 & 7.9 & 7.2 \\
Hartha Aquifers. D3 & 7.8 & 7.5 & 7.0 \\
Digma-Tayarat Aquifer. D4 & 7.6 & 7.5 & 7.1 \\
Muhaywir-Ubaid Aquifer. D5 & $/$ & 7.0 & $/$ \\
Ubaid-Mullusi Aquifer. D6 & 7.8 & 7.5 & 7.3 \\
Rattga-Digma-Tayarat Aquifers. D7 & 7.9 & 7.6 & 7.1 \\
Digma-Tayarat. D8 & 7.7 & 7.2 & 6.9 \\
\hline
\end{tabular}


Table 11. Frequency and TDS of the groundwater.

\begin{tabular}{|c|c|c|c|}
\hline Aquifer & $\begin{array}{c}\text { TDS (mg/l) at wells } \\
\text { percent of } 30 \% \text { to } 50 \%\end{array}$ & $\begin{array}{c}\text { TDS (mg/l) at wells } \\
\text { percent of } 50 \% \text { to } 90 \%\end{array}$ & $\begin{array}{l}\text { Wells percent at } \\
\text { TDS }<1000(\mathrm{mg} / \mathrm{l})\end{array}$ \\
\hline Ga'ra Aquifer. D1 & $6000-2500$ & $2500-280$ & $<30 \%$ \\
\hline Mullusi Aquifer. D2 & $1600-1000$ & $1000-460$ & $<50 \%$ \\
\hline Hartha Aquifer. D3 & $1400-800$ & $800-130$ & $<40 \%$ \\
\hline Digma-Tayarat Aquifer. D4 & $2100-1800$ & $1800-1000$ & $<10 \%$ \\
\hline Muhaywir-Ubaid Aquifer. D5 & $/-600$ & $600-1$ & $<50 \%$ \\
\hline Ubaid-Mullusi Aquifer. D6 & $1700-1000$ & $1000-400$ & $<50 \%$ \\
\hline Rattga-Digma-Tayarat Aquifer. D7 & $800-680$ & $680-400$ & $<85 \%$ \\
\hline Digma-Tayarat. D8 & $2600-1700$ & $1700-650$ & $<30 \%$ \\
\hline
\end{tabular}

3-Ubaid-Mullusi aquifer within district-6.

4-Muhaywir-Ubaid aquifer within district-5

5-Hartha aquifer within district-3.

6-Digma-Tayarat in district-8.

7-Ga'ra aquifer within district-1.

8-Digma-Tayarat aquifer within district-4.

\subsection{Groundwater Flow}

Specification of groundwater flow model is determined from the observation of groundwater levels depending on the results of measurements, using Groundwater Contour Software. The important scientific phenomena that can be extracted from the map of groundwater flow (Figure 15), supported by the following equations, Groundwater Flux (V) = KI [15] [61], where, I: hydraulic gradient, K: permeability. Groundwater pore velocity (U) = V/s [1] [62] where, V: groundwater Flux, s: specific yield or effective porosity.

-The groundwater of Gar'a aquifer (D1) within Rattga catchment area flows towards NE from hydraulic head of $591 \mathrm{~m}$ asl to $366 \mathrm{~m}$ asl and moves under the effort of hydraulic gradient of 0.0018 , rate of groundwater flux of $0.00036 \mathrm{~m} /$ day and rate of groundwater velocity of $0.042 \mathrm{~m} / \mathrm{day}$.

-The groundwater of Mullusi aquifer (D2) within Hauran catchment area moves towards NNE with local deviation towards NW in Traybil region and SE in Rutba region. The groundwater flows from hydraulic head of $736 \mathrm{~m}$ asl to $416 \mathrm{~m}$ asl under the effort of hydraulic gradient of 0.00128 , rate of groundwater flux of 0.00089 $\mathrm{m} /$ day and rate of groundwater velocity of $0.161 \mathrm{~m} /$ day.

-The groundwater of Hartha aquifer (D3) within the catchment area of Ubayidh tributaries flows toward NW from the hydraulic head of 711 to $516 \mathrm{~m}$ asl and moves under the effect of hydraulic gradient of 0.0022 , rate of groundwater flux of $0.00154 \mathrm{~m} /$ day and rate of groundwater velocity of $0.134 \mathrm{~m} /$ day.

-The groundwater of Digma-Tayarat aquifer (D4) within Alwalaj and Kharja catchment areas flows toward NW from the hydraulic head of 566 to $466 \mathrm{~m}$ asl. The groundwater moves under the effort of hydraulic gradient of 0.001 , rate of groundwater flux of $0.00058 \mathrm{~m} /$ day and rate of groundwater velocity of $0.089 \mathrm{~m} / \mathrm{day}$.

-The groundwater of Muhaywir-Ubaid aquifer (D5) within Hazimi catchment area flows toward east from the hydraulic head of 491 to $466 \mathrm{~m}$ asl. The groundwater moves under the effect of hydraulic gradient of 0.00067 , rate of groundwater flux of $0.0008 \mathrm{~m} /$ day and rate of groundwater velocity of $0.044 \mathrm{~m} /$ day.

-The groundwater of Mullusi-Ubaid aquifer (D6) within Dhabaa and Husayniyat catchment areas flows toward east and southeast from the hydraulic head of 516 to $441 \mathrm{~m}$ asl. The groundwater moves under the effort of hydraulic gradient of 0.003 , rate of groundwater flux of $0.0033 \mathrm{~m} /$ day and rate of groundwater velocity of 0.226 m/day.

-The groundwater of Rattga-Digma-Tayarat aquifer (D7) within Swab and Akash catchment areas flows toward east and northeast from the hydraulic head of 541 to $366 \mathrm{~m}$ asl. The groundwater moves under the effect of hydraulic gradient of 0.0016 , rate of groundwater flux of $0.026 \mathrm{~m} /$ day and rate of groundwater velocity of $0.634 \mathrm{~m} / \mathrm{day}$.

-The groundwater of Digma-Tayarat aquifer within district-8 flows toward Rattga valley from the hydraulic head of 416 to $366 \mathrm{~m}$ asl. The groundwater moves under the effort of hydraulic gradient of 0.001, rate of groundwater flux of $0.00021 \mathrm{~m} /$ day and rate of groundwater velocity of $0.023 \mathrm{~m} /$ day. The model of flow behavior determines a preferable site for groundwater exploitation under active hydrodynamic conditions, represented by high groundwater flux and high groundwater pore velocity. The model results are summarized in the following 


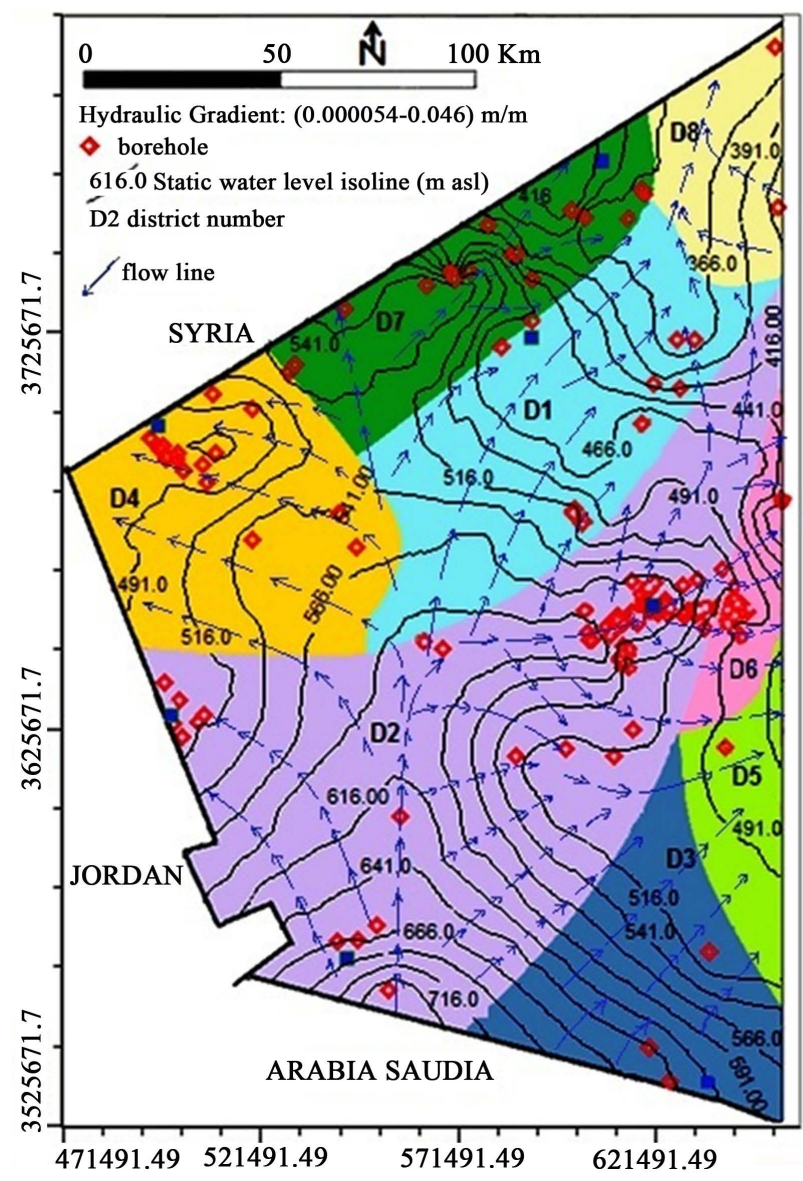

Figure 15. Groundwater flow model within study area.

preferable output:

1-Rattga and Digma-Tayarat aquifer within district-7.

2-Ubaid Mullusi aquifer within district-6.

3-Mullusi aquifer within district-2.

4-Hartha aquifer within district-3.

5-Digma-Tayarat aquifer within district-4.

6-Muhaywir-Ubaid aquifer within district-5

7-Ga'ra aquifer within district-1.

8-Digma-Tayarat in district-8.

\section{Conclusions}

The study identifies the hydrogeological properties and hydraulic characteristics of the aquifers within the hydrogeologic system. An integrated approach combining geo-structural settings and geological boundaries, supported by spatial bimodel of hydrodynamic distribution were achieved to define the hydrogeological facts of the aquifers and to determine the behaviour of groundwater flow and recharge. Details of the hydrogeologic information for aquifers in eight hydrogeologic districts comprising hydraulic and hydro-chemical parameters such as volume of recharge water, permeability, transmissivity, storativity, groundwater depths, TDS of groundwater and hydrodynamic activity (groundwater velocity), are used in selection best hydrogeologic region for groundwater exploitation. The preference and screening among aquifers were performed depending on each factor of the transactions, where the aquifer of first grade, takes eight weights than the aquifer of the eighth grade (e.g. first aquifer gets eight weights, second aquifer gets seven weights, till eighth aquifer gets one weight). Based on above mentioned details, the aquifer that collects high weights becomes the first choice for investment and so on 
Table 12. Evaluation of preference grade for aquifers.

\begin{tabular}{|c|c|c|c|c|c|c|c|c|}
\hline Aquifer & TDS & $\begin{array}{l}\text { Hydrodynamic } \\
\text { activity }\end{array}$ & $\begin{array}{l}\text { Water } \\
\text { depth }\end{array}$ & $\begin{array}{l}\text { Storativity } \\
\text { (s) }\end{array}$ & $\begin{array}{c}\text { Transmissivity } \\
\text { (T) }\end{array}$ & $\begin{array}{l}\text { Permeability } \\
\text { (K) }\end{array}$ & $\begin{array}{c}\text { Volume of } \\
\text { recharge water }\end{array}$ & $\begin{array}{c}\text { Total } \\
\text { weight }\end{array}$ \\
\hline Gar'a in D-1 & 2 & 2 & 6 & 4 & 7 & 2 & 7 & 30 \\
\hline Mullusi in D-2 & 7 & 6 & 5 & 2 & 2 & 4 & 8 & 34 \\
\hline Hartha in D-3 & 4 & 5 & 1 & 7 & 4 & 5 & 5 & 31 \\
\hline Digma-Tayarat in D-4 & 1 & 4 & 2 & 3 & 8 & 7 & 6 & 31 \\
\hline Muhaywir-Ubaid in D-5 & 5 & 3 & 3 & 6 & 6 & 1 & 3 & 27 \\
\hline Mullusi-Ubaid in D-6 & 6 & 7 & 8 & 8 & 1 & 6 & 1 & 39 \\
\hline Rattga-Tayarat in D-7 & 8 & 8 & 4 & 1 & 3 & 8 & 4 & 36 \\
\hline Digma-Tayarat in D-8 & 3 & 1 & 7 & 5 & 5 & 3 & 2 & 26 \\
\hline
\end{tabular}

as shown in Table 12. The study confirmed the priority choices for the best districts which can be exploited in the future, as follows in the descending order.

-Ubaid-Mullusi aquifer within district No.6.

-Rattga-Jeed aquifer within district No.7.

-Mullusi aquifer within district No.2.

-Hartha aquifer within district No.3.

-Digma-Tayarat (Jeed) aquifer within district No.4.

-Ga'ra aquifer within district No.1.

-Muhaywir-Ubaid aquifer within district No.5.

-Digma-Tayarat (Jeed) aquifer within district No.8.

\section{References}

[1] Fitts, C. (2002) Groundwater Science. Elsevier Science Ltd., Kidlington, 450 p.

[2] Lachaal, F., Mlayah, A., Anane, M., Bédir, B., Tarhouni, J. and Leduc, C. (2011) Comprehension and Hydrogeological Concept-Utilization of Aquifer in Arid and Semi Arid Regions Using Integrated Hydrogeological Information System: Case of the Deep Aquifer of Zéramdine-Béni Hassen. Arabian Journal of Geosciences.

[3] Ayenew, T., Demlie, M. and Wohnlich, S. (2008) Hydrogeological Framework and Occurrence of Groundwater in the Ethiopian Aquifers. Journal of African Earth Sciences, 52, 97-113. http://dx.doi.org/10.1016/j.jafrearsci.2008.06.006

[4] Yin, L., Hu, G., Huang, J., Wen, D., Dong, J., Wang, X. and Li, H. (2011) Groundwater-Recharge Estimation in the Ordos Plateau, China: Comparison of Methods. Hydrogeology Journal, 19, 1563-1575. http://dx.doi.org/10.1007/s10040-011-0777-3

[5] Healy, R. and Cook, P. (2002) Using Groundwater Levels to Estimate Recharge. Hydrogeology Journal, 10, 91-109.

[6] Fawcett, J., Cherry, D. and Reid, M. (2006) Hydrogeological Units of the Upper London and Spring Hill Groundwater Management Units. Department of Primary Industries, Melbourne.

[7] Bruce, G., Cherry, D., Adelana, M., Xiang, C. and Mark, R. (2011) Using Three-Dimensional Geological Mapping Methods to Inform Sustainable Groundwater Development in a Volcanic Landscape, Victoria, Australia. Hydrogeology Journal, 19, 1349-1365.

[8] Andrzej, J., Andrzej, K. and Vrba, J. (2007) Groundwater Vulnerability, Assessment and Mapping Selected Papers from the Groundwater, Vulnerability Assessment and Mapping. International Conference, Ustron, Poland, 2004, UNESCO Consultant and Chairman of IAH Commission on Groundwater Protection, Prague, Czech Republic/New York /Philadelphia, c 2007 Taylor and Francis Group, London.

[9] Stephen, J. and Carleton, G. (2005) Hydrogeology and Simulated Effects of Ground-Water Withdrawals, KirkwoodCohansey Aquifer System, Upper Maurice River Basin Area, New Jersey, Scientific Investigations Report 2005-5258. US Department of the Interior, US Geological Survey, $48 \mathrm{p}$.

[10] Fetter, C. (1988) Applied Hydrogeology. Merrill Publishing, Columbus, 592.

[11] Heath, R. (2004) Basic Groundwater Hydrology, US Geological Survey Water Supply. Paper 2220, 91 p.

[12] Freeze, R. and Cherry, J. (1987) Groundwater. Prentice-Hall International, London, 524. 
[13] Weight, W. (2004) Manual of Applied Hydrogeology. McGraw-Hill, New York, 553 p.

[14] William, M., Thomas, E. and Franke, O. (1999) Sustainability of Ground-Water Resources, US Geological Survey Circular 1186, Denver, US Government Printing Office, Free on application to the US Geological Survey Branch of Information Services, Box25286 Denver, 80225-0286 Library of Congress Cataloging-in-Publications Data.

[15] Todd, D. and Mays, L. (2005) Groundwater Hydrology. 3rd Edition, John Wiley and Sons, Inc., Hoboken, 652 p.

[16] Hamza, N. (2007) Geomorphology of the Iraqi Western Desert. Iraqi Bulletin of Geology and Mining, 0, 9-29.

[17] Hamza, N. (1997) Geomorphological Map of Iraq, Scale 1: 1000 000. Geosurv, Baghdad.

[18] Gems/Grid of United Nation Environments Programme 1991 in World Environment Day (2006) Status of Desertification and Implementation of the United Nation Plan of Action to Combat Desertification. m5-Files/Unep-status.

[19] CDS (2010) Hydrogeologic Evaluation of Mullusi Aquifer and Groundwater Properties within Dhabaa Region East of Rutba. Internal Report, Center of Desert Studies, Al-Anbar University, Ramadi, 170 p.

[20] Yugoslavia, C. (1981) Regional Hydro Geological Study for Block No. 5 (Rutba Area) \& for Block No. 7, RamadiAna-K-160, Unpublished Study. Ministry of Irrigation.

[21] Al-Jabbari, M., Hassan, Q. and Imad, M. (2002) The Water Resources in Euphrates Basin. Unpublished Study, Ministry of Agriculture, $524 \mathrm{p}$.

[22] ACSAD (1983) Groundwater Resources of Al-Hamad Basin. No. 13, Final Report, Annex-4 Al-Hamad Basin Studies, Damascus (In Arabic).

[23] Mazor, E. and Nativ, R. (1992) Hydraulic Calculation of Groundwater Flow Velocity and Age: Examination of the Basic Premises. Journal of Hydrology, 138, 211-222. http://dx.doi.org/10.1016/0022-1694(92)90165-R

[24] U.S.EPA (1989) Intérim Final Guidance on Statistical Analysis of Groundwater Monitoring Data at RCRA Facilities.

[25] Walton, W. (1970) Groundwater Resource Evaluation. McGraw-Hill Series, 664 p.

[26] Thornhill, T. (1989) Accuracy of Depth to Water Measurements, US EPA Superfund Groundwater Issue, EPAu540u489-002, Robert S. Kerr Environmental Research Laboratory, Ada, 3 p.

[27] Plazak, D. (1994) Differences between Water Level Probes, GW. Monitoring and Remediation, 14, 84 p.

[28] Nielsen, D. and Nielsen, G. (2005) The Essential Hand Book of Groundwater Sampling. CRC Press Taylor \& Francis Group 6000 Broken Sound Parkway NW, Suite 300 Boca Raton, 33487-2742, 326 p.

[29] Driscoll, G. (1986) Groundwater and Wells. Johnson Division, Saint Paul, 1089 p.

[30] Barcelona, J., Gibb, P., Helfrich, A. and Garske, E. (1985) Practical Guide for Groundwater Sampling, EPA-600u285104, US, EP Agency, Robert S. Kerr Environmental Research Laboratory, Ada, 78-80.

[31] Bollenbach, W. (1975) Groundwater and Wells, A Reference Book for the Water Well Industry. Johnson Division, UOP Inc., Saint Paul, 440 p.

[32] Nielsen, D. (2006) The Practical Handbook of Environmental Site Characterization and Groundwater Monitoring. 2nd Edition, CRC Press/Taylor and Francis Group, Boca Raton, 1318 p.

[33] Turner, A. (1991) Three-Dimensional Modelling with Geoscientific Information Systems. Kluwer, Dordrecht, 443 p.

[34] Berg, R., Russel, H. and Thorleifson, L. (2009) Introduction: Three Dimensional Geologic Mapping-International Perspective. Three Dimensional Geologic Mapping Workshop GSA Portland Oregon. http://www.isgs.Uiuc.edu/research/3DWorkshop/2009/workshop.shtml

[35] McKay, E. (2011) Illinois S. Geological Survey (29011) Three-Dimensional Geological Mapping for Ground Water Applications Workshops. http://www.isgs.uiuc.edu/research/3DWorkshop/index. shtml. Cited May 2011

[36] Sissakian, V. (2007) The Origin of the Subsurface Igneous Clastics Accumulation in Al-Tinf Vicinity, West Iraq, a New Concept. Iraqi Bulletin of Geology and Mining, 3, 11-24.

[37] Jasim, S. and Goff, J. (2006) Geology of Iraq, Published by Dolin, Prague \& Moravian Museum Brno. Zech. Repub.

[38] Al-Mubarak, M. (1996) Regional Geological Setting of the Central Part of the Iraqi Western Desert. Iraqi Geological Journal, 29, 64-83.

[39] Fouad, S. (2007) Tectonic and Structural Evolution of the Iraqi Western Desert. Iraqi Bulletin of Geology and Mining, 0, 29-51.

[40] Al-Bassam, K., Al-Azzawi, A., Dawood, R. and Al-Bedaiwi, J. (2004) Subsurface Study of the Pre Cretaceous Regional Unconformity in the Western Desert of Iraq. Iraqi Geological Journal, 32-33, 1-25.

[41] Hussien, B.M. (2010) Hydrogeologic Condition within Al-Anbar Governorate. Journal of Anbar University for Pure Science, 4, 97-111.

[42] Al-Hadithi, T., Al-Amiri, H. and Al-Mehaidi, H. (1978) Report on Geological Photo-Interpretation of Rutba Area, Block-5. Internal Report, Geosurv, 51 p. 
[43] Abas, M. (1985) Analysis of Gravity Lineaments in Western Desert. Journal of the Geological Society of Iraq, 18, 3746.

[44] Al-Mubarak, M. and Amin, R. (1983) Report on the Regional Geological Mapping of the Eastern Part of the Western desert and Western Part of the Southern Desert. Geosurv Internal Report No. 1380.

[45] Al-Naqib, S., Said, I., Taha, Y., Al-Sharbati, F., Yakta, S., Hussien, M., Yacoub, I. and Al-Mukhtar, L. (1986) Detailed Geological Survey of Rutba Area. Geosurv Internal Report No. 1560.

[46] Sissakian, V. and Mahmud, B. (2007) Stratigraphy of the Iraqi Western Desert. IBGM, SCGSM, 51-125.

[47] Al-Azzawi, A. and Dawood. R. (1996) Report on Detailed Geological Survey in North West of kilo-160, Rutba Area. Geosurv Internal Report No. 2491.

[48] Buday, T. and Hack, J. (1980) Report on Geological Survey of the Western Part of the Western Desert, Iraq. Geosurv Internal Report No. 1000.

[49] Jassim, S., Karim, S., Basi, M., Al Mubarak, M. and Mansour, J. (1984) Final Report of the Regional Geological Survey of Iraq. Vol. 3, Geosurv.

[50] Hussien, B.M. (2013) Modeling the Impact of Groundwater Depletion on the Hydrochemical Characteristic of Groundwater within Mullusi Carbonate Aquifer-West Iraq. Environmental Earth Sciences, 70, 453-470. http://dx.doi.org/10.1007/s12665-012-2139-4

[51] Hussien, B.M. (2012) Management of Groundwater Resources in Dhabaa Site Using Hydraulic Parameters of Mullusi Aquifer. Journal of Iraqi Desert Studies, 4.

[52] Hussien, B.M. (2010) Application of Environmental Isotopes Technique in Groundwater Recharge within Mullusi Carbonate Aquifer-West Iraq. Journal of Iraqi Desert Studies, 2.

[53] Araim, H. (1990) Regional Hydrological Map of Iraq. Scale 1: 1000 000. Geosurv.

[54] Hassan, A. and Zeki, N. (1982) Water Availability Periods and Water Balance Parameters. JRAWR, Vol. 1, Council for Scientific Research, Baghdad.

[55] Laboutka, M. (1974) The Hydrogeological Tables and Data. The Basic Instructions No. 3 Report No. 8. National Iraqi Minerals Company, Baghdad.

[56] Helsel, D. and Hirsch, R. (2002) Chapter A3, Statistical Methods in Water Resources. Techniques of Water Resources Investigations of the United States Geological Survey, Book 4, Hydrologic Analysis and Interpretation. http://water.usgs.gov/pubs/twri/twri4a3

[57] Bedient, P. and Huber, W. (1988) Hydrology and Floodplain Analysis. Addison-Wesley Publishing Company, Boston, $650 \mathrm{p}$.

[58] Hem, J. (1990) Study and Interpretation of the Chemical Characteristics of Natural Water. 3rd Edition, USGS Water Supply, Paper 2254, 263 p.

[59] Matthess, G. (1982) The Properties of Groundwater. Department of E Science. J. Wiley and Sons Inc., New York, 406 p.

[60] Collin's, A. (1975) Geochemistry of Oil Field Water. Development in Petroleum Science-1, Holland, 496 p.

[61] IAEA, (1984) Safety Series, No. 50, SG-S7, Nuclear Power Plants Siting, Hydrogeologic Aspects, a Safety Guide. Vienna, $77 \mathrm{p}$.

[62] Huisman, L. (1972) Groundwater Recovery. Macmillan Publishers, London. 
Scientific Research Publishing (SCIRP) is one of the largest Open Access journal publishers. It is currently publishing more than 200 open access, online, peer-reviewed journals covering a wide range of academic disciplines. SCIRP serves the worldwide academic communities and contributes to the progress and application of science with its publication.

Other selected journals from SCIRP are listed as below. Submit your manuscript to us via either submit@scirp.org or Online Submission Portal.
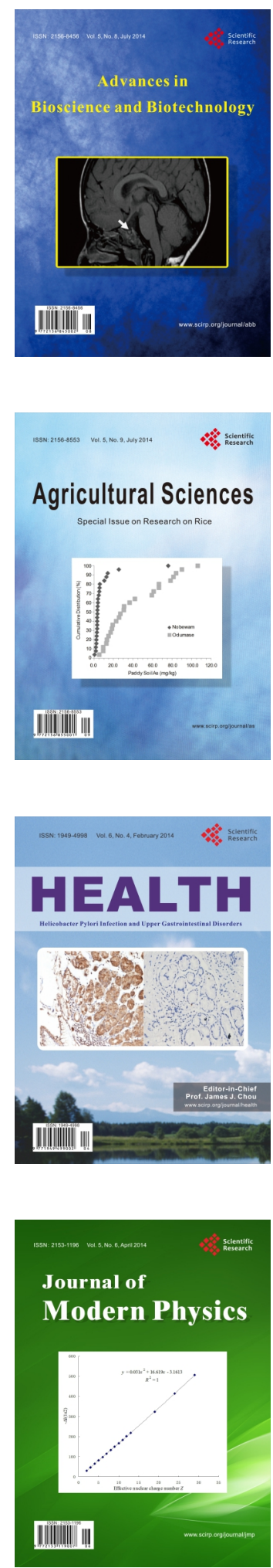
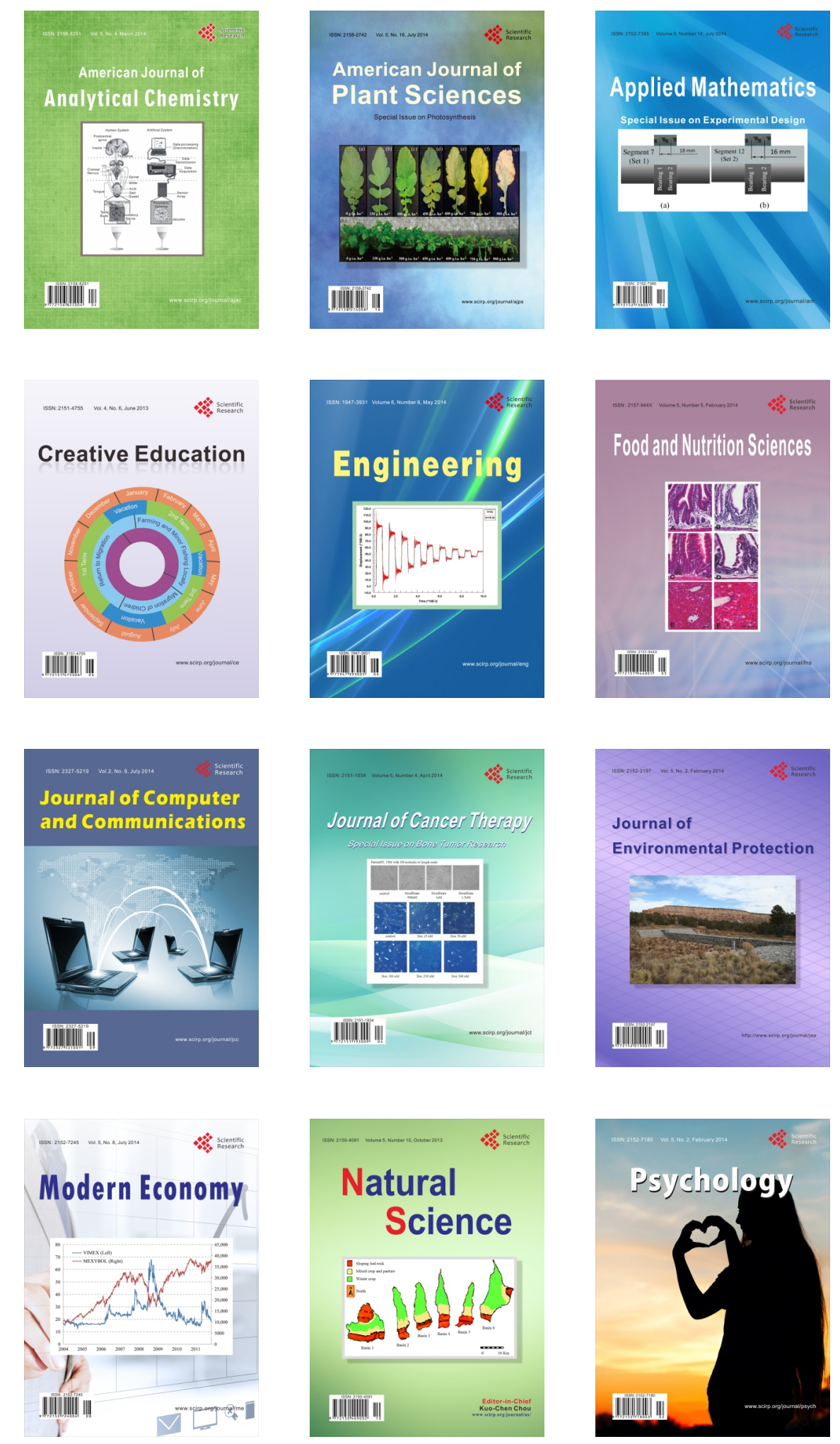